\title{
Skeletal and Bone Mineral Density Features, Genetic Profile in Congenital Disorders of Glycosylation: Review
}

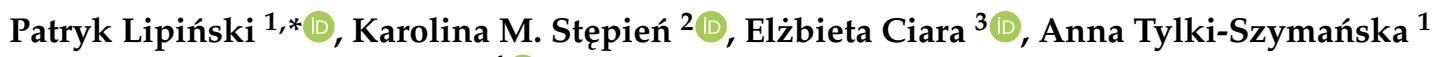 \\ and Aleksandra Jezela-Stanek 4 (i) \\ 1 Department of Pediatrics, Nutrition and Metabolic Diseases, The Children's Memorial Health Institute, \\ 04-730 Warsaw, Poland; A.Tylki@ipczd.pl \\ 2 Adult Inherited Metabolic Diseases, Salford Royal NHS Foundation Trust, Salford M6 8HD, UK; \\ kstepien@doctors.org.uk \\ 3 Department of Medical Genetics, The Children's Memorial Health Institute, 04-730 Warsaw, Poland; \\ e.ciara@ipczd.pl \\ 4 Department of Genetics and Clinical Immunology, National Institute of Tuberculosis and Lung Diseases, \\ 01-138 Warsaw, Poland; jezela@gmail.com \\ * Correspondence: p.lipinski@ipczd.pl
}

Citation: Lipiński, P.; Stępień, K.M.; Ciara, E.; Tylki-Szymańska, A.; Jezela-Stanek, A. Skeletal and Bone Mineral Density Features, Genetic Profile in Congenital Disorders of Glycosylation: Review. Diagnostics 2021, 11, 1438. https://doi.org/ 10.3390/diagnostics11081438

Academic Editor: Evangelos Terpos

Received: 13 July 2021

Accepted: 4 August 2021

Published: 9 August 2021

Publisher's Note: MDPI stays neutral with regard to jurisdictional claims in published maps and institutional affiliations.

Copyright: (c) 2021 by the authors. Licensee MDPI, Basel, Switzerland. This article is an open access article distributed under the terms and conditions of the Creative Commons Attribution (CC BY) license (https:/ / creativecommons.org/licenses/by/ $4.0 /)$.

\begin{abstract}
Congenital disorders of glycosylation (CDGs) are a heterogeneous group of disorders with impaired glycosylation of proteins and lipids. These conditions have multisystemic clinical manifestations, resulting in gradually progressive complications including skeletal involvement and reduced bone mineral density. Contrary to PMM2-CDG, all remaining CDG, including ALG12CDG, ALG3-CDG, ALG9-CDG, ALG6-CDG, PGM3-CDG, CSGALNACT1-CDG, SLC35D1-CDG and TMEM-165, are characterized by well-defined skeletal dysplasia. In some of them, prenatal-onset severe skeletal dysplasia is observed associated with early death. Osteoporosis or osteopenia are frequently observed in all CDG types and are more pronounced in adults. Hormonal dysfunction, limited mobility and inadequate diet are common risk factors for reduced bone mineral density. Skeletal involvement in CDGs is underestimated and, thus, should always be carefully investigated and managed to prevent fractures and chronic pain. With the advent of new therapeutic developments for CDGs, the severity of skeletal complications may be reduced. This review focuses on possible mechanisms of skeletal manifestations, risk factors for osteoporosis, and bone markers in reported paediatric and adult CDG patients.
\end{abstract}

Keywords: congenital disorder of glycosylation; growth; skeletal dysplasia; cartilage; joint; bone markers; osteoporosis

\section{Introduction}

Congenital Disorders of Glycosylation (CDGs) are a clinically heterogenous group of over 150 diseases caused by defects in different steps of glycan metabolism pathways [1,2]. These genetic disorders are characterized by an impaired synthesis and attachment of glycans to glycoproteins and glycolipids, and impaired synthesis of glycosylphosphatidylinositol (GPI) (Figure 1) [1]. These disorders are categorized into (a) protein $N$-glycosylation defects; (b) protein O-glycosylation defects; (c) glycolipid and GPI anchor synthesis defects and (d) multiple glycosylation pathways and other pathways defects [2]. 


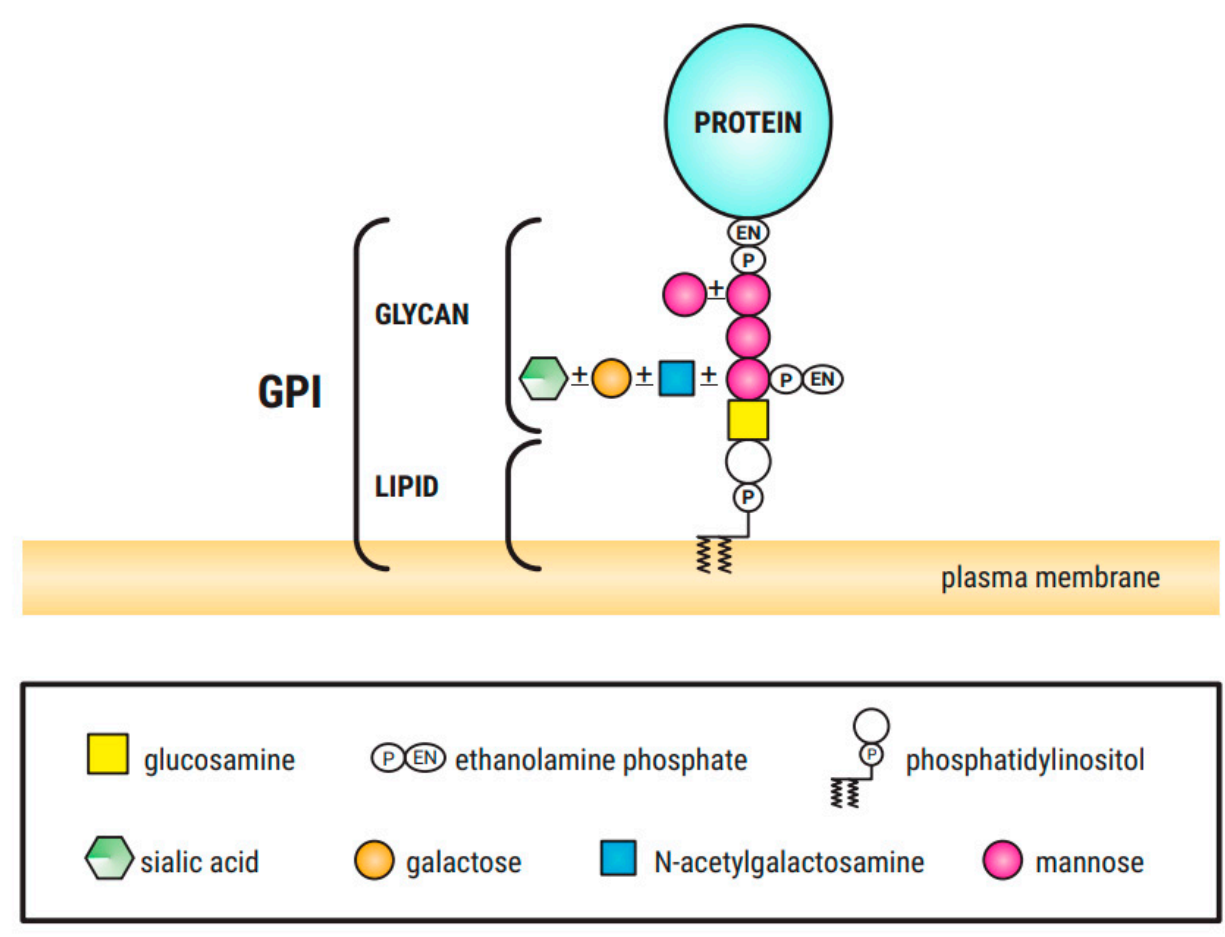

Figure 1. GPI structure, consisting of the conserved core glycan, phosphatidylinositol and glycan side chains ([3], own modification).

Among the different glycosylation defects, impaired protein $N$-glycosylation is the most common. Glycan processing (remodeling) takes place in the endoplasmic reticulum (ER) and Golgi apparatus [2]. O-glycosylation occurs in the Golgi apparatus and no lipidlinked intermediates are involved. In contrast to $\mathrm{N}$-glycosylation, the process involves only the sequential addition of monosaccharides without remodeling [2,4]. Abnormalities in the synthesis of $O$-linked $N$-acetylglucosamine, galactose (Gal), mannose (Man), glucose (Glc) and fucose (Fuc) glycans have also been described [5]. GPI is a phosphoglyceride (Figure 1) that acts as a membrane anchor of proteins to the outer leaflet of the cellular membrane. GPI-anchor biosynthesis defects (GPI-BD) are categorized by an inappropriate GPI-anchors biosynthesis or modification (protein attachment, structural remodeling at both glycan and parts of GPI). Most of the CDGs have autosomal recessive pattern of inheritance, but autosomal dominant and X-linked forms have also been described. To date, about 80 different entities have been described in correlation with congenital disorder of glycosylation or CDG-like diseases. Although some genotype-phenotype correlation has been proposed, there is a significant phenotypic variability within the same genotype.

Glycosylation is key for a variety of posttranslational biological processes including main components of the hormone cascades regulating growth and metabolism $[5,6]$. As a result, CDG patients present with very diverse clinical phenotypes, with multi-system involvement [4-7]. These include cognitive impairment, neurological (epilepsy, hypotonia, ataxia and polyneuropathy), ophthalmological, skeletal, cardiac, hepatic, haematological and endocrinological phenotypes $[1,2,7,8]$.

The mechanisms of bone disease in CDGs seem to be multifactorial. Malabsorption and liver dysfunction lead to a poor nutritional state which impacts the growth hormoneinsulin-like growth factor (GH/IGF) axis and results in a short stature $[9,10]$. Given that patients with CDGs manifest their skeletal abnormalities in childhood, one may speculate that they are attributed to the impaired glycosylation in the bone tissue in the early stages of life.

So far, there have been no therapies targeting specific organ such as eye, kidney, heart, muscles or skeleton, with only supportive management being available [10]. 
This review describes skeletal manifestations and bone mineral density abnormalities in paediatric and adult CDG patients with the aim to discuss the heterogeneity of clinical manifestations and correlate the genetic data (causative genes) with observed skeletal phenotype to evaluate the potential mechanism of mutational effect on the phenotype.

\section{Skeletal Abnormalities}

\subsection{Skeletal Characteristics of PMM2-CDG}

PMM2-CDG is the most prevalent disorder of abnormal glycosylation of $N$-linked oligosaccharides leading to endocrine abnormalities including dysfunction of IGFBP3 and an acid-labile subunit in the IGF pathway which result in short stature [11]. Growth failure is commonly observed in children with PMM2-CDG [7,12-17]. Despite normal serum calcium, phosphate and magnesium concentrations, osteopenia/osteoporosis are frequently demonstrated in this condition since childhood (Table 1) [8-14]. Skeletal abnormalities are common, although under-diagnosed [17], often leading to kypho/scoliosis, severe spinal cord deformity and vertebral compression fractures [7] (see Figure 2). Regular orthopaedic assessment and intervention are required if scoliosis becomes evident, with cervical spine $x$-rays in neutral, flexion, and extension to assess for atlantoaxial instability. Fractures are common and appear to heal normally. Skeletal dysplasia is not a typical feature of PMM2-CDG but has been reported before (Tables 1 and 2). Joint contractures are relatively common and affect patients' quality of life. 


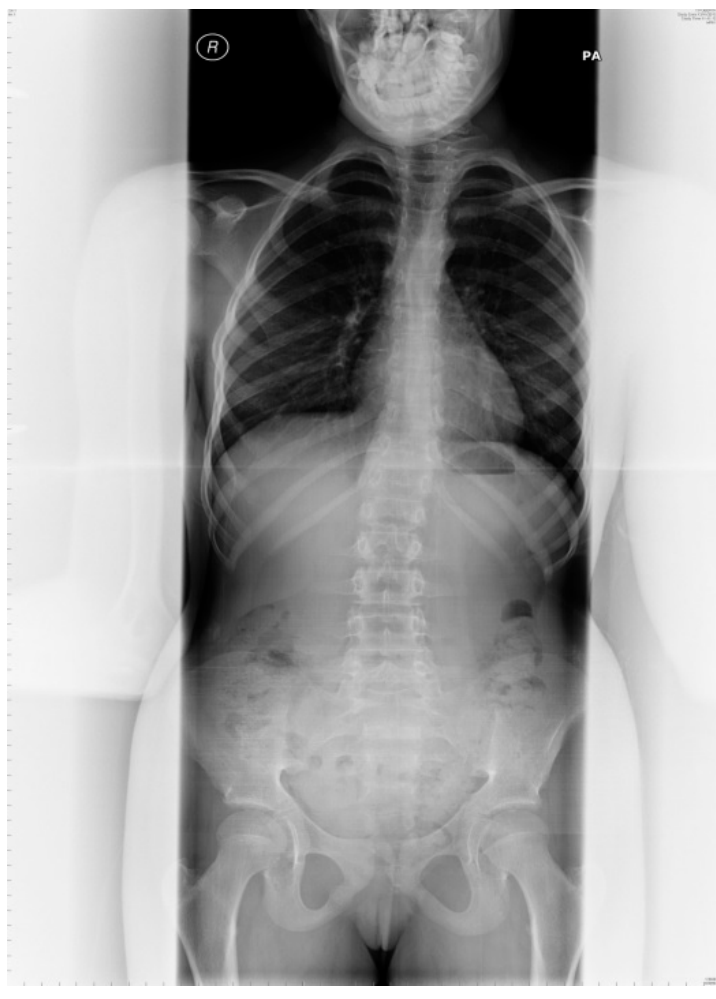

(a)

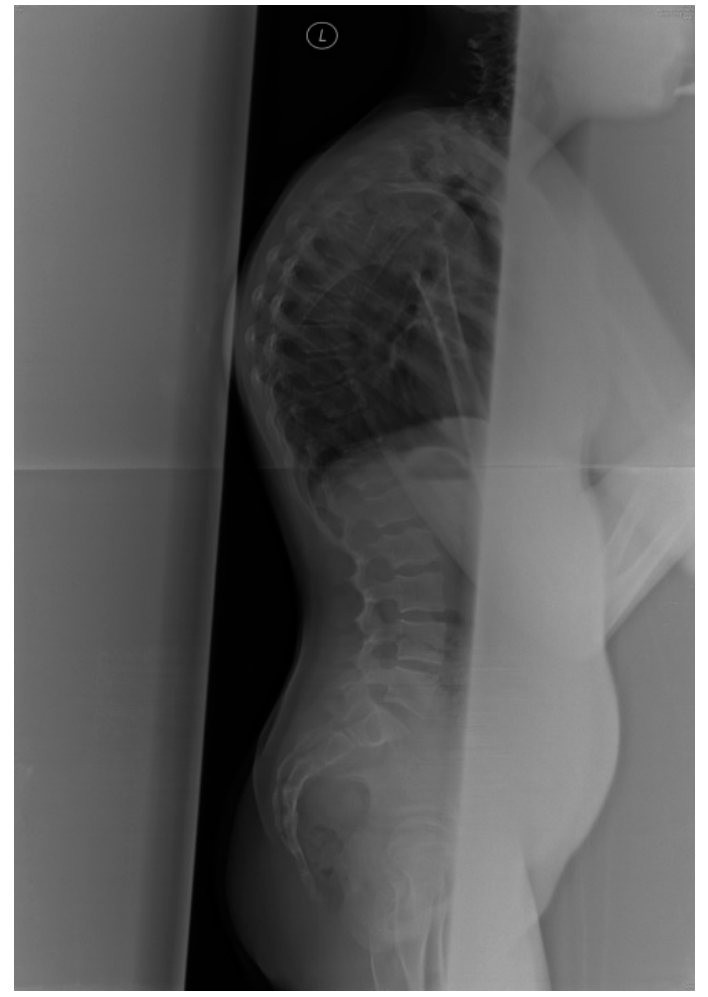

(b)

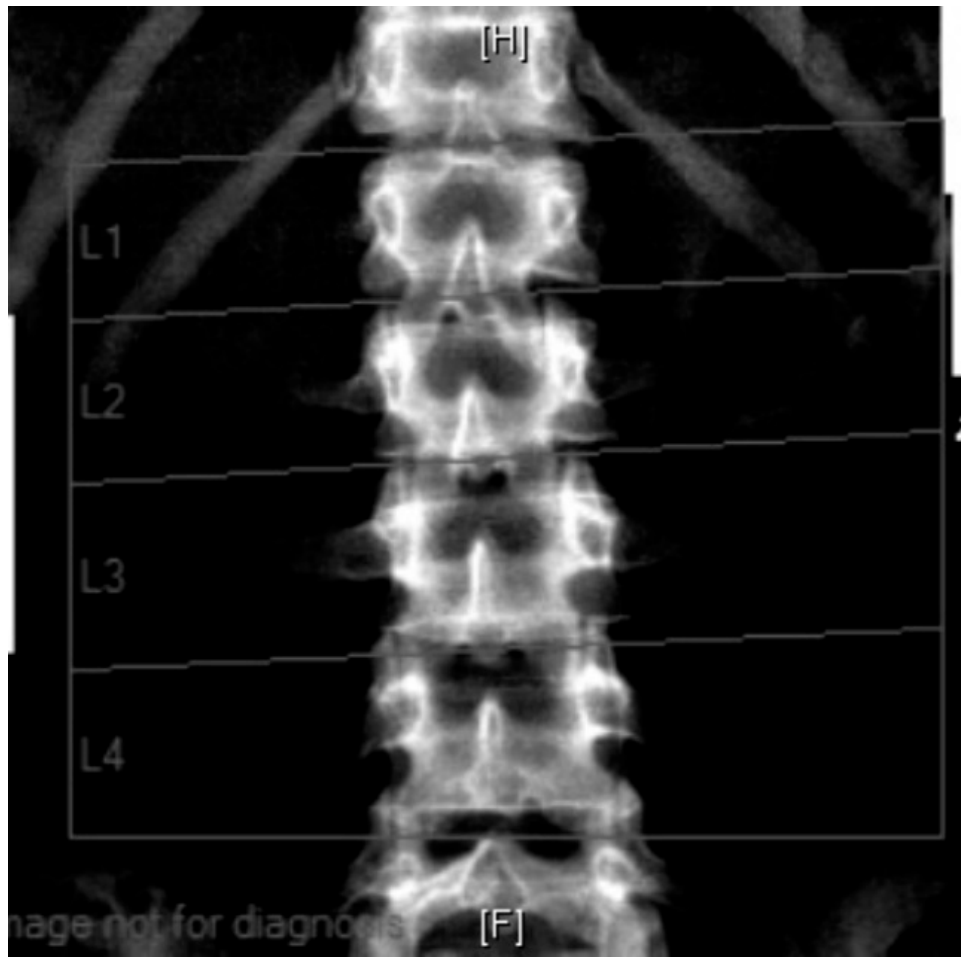

(c)

Figure 2. (a) Anterior posterior view-whole spine x-ray in a 25-year-old female patient affected with PMM2-CDG; bone mineral density is below expected for her age (T score -2.6, z-score -2.6); (b) lateral view; (c) radiological features of her lumbar spine: there is a double mild curve scoliosis and no rotational deformity. All pedicles are visualized. There is impression of slight upper hyperkyphosis and impression of multilevel Schmorl's nodes. 
Table 1. Skeletal phenotype in various CDG types.

\begin{tabular}{|c|c|c|c|c|c|c|c|c|c|c|c|c|c|c|c|c|c|c|c|c|}
\hline CDG Type & 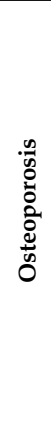 & 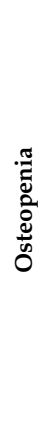 & 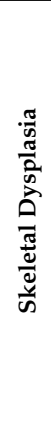 & 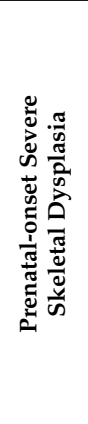 & 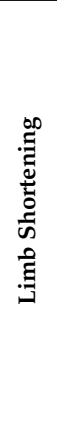 & 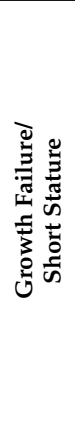 & 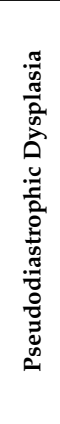 & 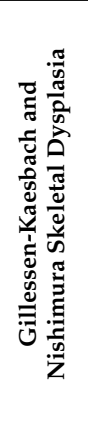 & 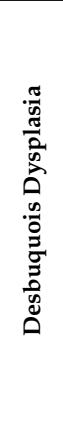 & 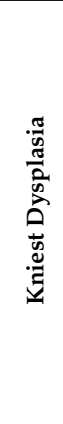 & 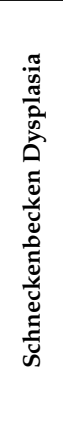 & 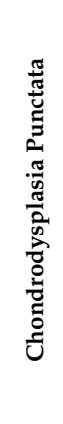 & 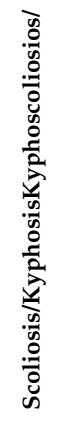 & 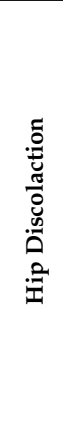 & 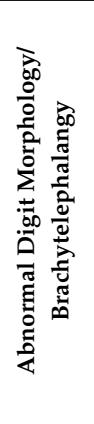 & 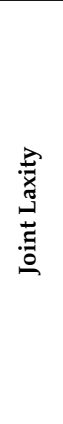 & 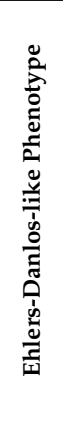 & 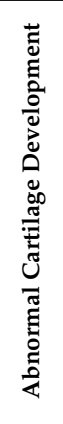 & 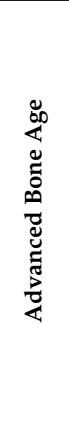 & 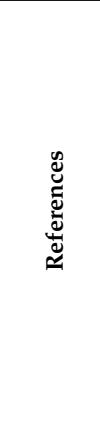 \\
\hline PMM2-CDG & + & + & + & & + & + & & & & + & & & & & & & & & & [11-21] \\
\hline ALG12-CDG & & & + & & + & + & + & & & & & & + & & & & & & & [22-25] \\
\hline ALG3-CDG & & & + & + & + & + & & & & & & + & & & & & & & & [26] \\
\hline ALG9-CDG & & & + & + & + & + & & + & & & & & + & + & & & & & & [27-30] \\
\hline ALG6-CDG & & & & & & & & & & & & & & & + & & & & & {$[31,32]$} \\
\hline PGM3-CDG & & & + & + & + & + & & & + & & & & & & & & & & & [33-36] \\
\hline COG7-CDG & & & + & & + & + & & & & & & & & & & & & & & {$[37,38]$} \\
\hline COG1-CDG & & & + & & + & + & & & & & & & & & & & & & & [39] \\
\hline COG8-CDG & & & + & & + & + & & & & & & & & & & & & & & {$[40]$} \\
\hline CSGALNACT1-CDG & & & + & & + & + & & & + & & & & & & & + & & + & & {$[41,42]$} \\
\hline SLC35D1-CDG & & & + & + & + & + & & & & & + & & + & & & & & & + & {$[43,44]$} \\
\hline B4GALT7-CDG & & + & + & & & + & & & & & & & & & & + & + & & & {$[45-48]$} \\
\hline B3GAT3-CDG & & + & + & & & + & & & & & & & + & & & + & + & & & [49] \\
\hline TMEM165-CDG & + & + & + & & & + & & & + & & & & + & & & + & & + & & {$[50]$} \\
\hline $\begin{array}{l}\text { GPI-biosynthesis } \\
\text { defects }\end{array}$ & & & + & & & & & & & & & & & & + & & & & & [51-59] \\
\hline
\end{tabular}




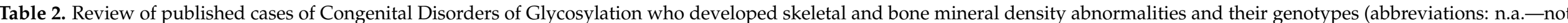
analysed; Pt—patient; pc-percentile).

\begin{tabular}{|c|c|c|c|c|c|}
\hline $\begin{array}{l}\text { CDG Type and Related Gene } \\
\text { (RefSeq) }\end{array}$ & Molecular Variant and Protein Change & Bone/Skeletal Manifestation & Clinical and Radiological Findings & Outcome & References \\
\hline \multirow{2}{*}{$\begin{array}{l}\text { ALG12-CDG (\# 607143); } \\
\text { ALG12 (NM_024105.4) }\end{array}$} & $\begin{array}{l}\text { c.301G > A (p.Gly101Arg)/ } \\
\text { c.437G > A (p.Arg146Gln) } \\
\text { compound heterozygote; } \\
2 \text { pts (siblings) }\end{array}$ & severe skeletal dysplasia & $\begin{array}{l}\text { Talipes equinovarus, short flared ribs, ulnar deviation of } \\
\text { the wrists, delayed ossification of cervical vertebrae, } \\
\text { generalized epiphyseal dysplasia. }\end{array}$ & $\begin{array}{l}\text { very severe clinical phenotype; } \\
\text { Pt } 1 \text { died at age } 23 \text { months due to sepsis } \\
\text { secondary to hypogammaglobulinemia; } \\
\text { Pt } 2 \text { died at age } 67 \text { days secondary to } \\
\text { cardiomyopathy. }\end{array}$ & [21] \\
\hline & $\begin{array}{l}\text { c.117del (p.Gln40Argfs*34) / } \\
\text { c.1001del (p.Asn334Thrfs*15) } \\
\text { compound heterozygote; } \\
1 \text { pt }\end{array}$ & severe skeletal dysplasia & $\begin{array}{l}\text { Interphalangeal dislocations, scoliosis, talipes equinovarus, } \\
\text { rhizomelic limb shortening, short metacarpals, somewhat } \\
\text { horizontal acetabular roof (similar to pseudodiastrophic } \\
\text { dysplasia), ulnar deviation of the wrists. }\end{array}$ & $\begin{array}{l}\text { pregnancy complicated by } \\
\text { polyhydramnios; } \\
\text { Pt died in the neonatal period. }\end{array}$ & [22] \\
\hline $\begin{array}{l}\text { ALG3-CDG (\# 601110); } \\
\text { ALG3 (NM_ 005787.6) }\end{array}$ & $\begin{array}{l}\text { c.286G > A (p.Gly96Arg) } \\
\text { homozygote; } \\
2 \text { pts }\end{array}$ & severe skeletal dysplasia & $\begin{array}{l}\text { Pt 1-IUGR with short limbs. After birth-limb rhizomelic } \\
\text { shortening with short and stubby long bones, wide } \\
\text { metaphyses, hypoplastic cervical vertebrae, a narrow } \\
\text { thorax with short ribs and rounded iliac wings. } \\
\text { Chondrodysplasia punctata (CDP) in a symmetrical } \\
\text { pattern observed in tarsal and carpal bones, patellae, hips } \\
\text { and upper airways. } \\
\text { Pt } 2 \text {-skeletal dysplasia including short and stubby long } \\
\text { bones with wide metaphyses, wide phalanges and } \\
\text { metacarpals with increased metaphyseal density, narrow } \\
\text { thorax, hypoplastic cervical vertebral bodies and rounded } \\
\text { iliac wings. }\end{array}$ & $\begin{array}{l}\text { Pt1- termination of pregnancy at } 25 \\
\text { weeks of gestation; } \\
\text { Pt } 2 \text { died at } 12 \text { days due to heart failure. }\end{array}$ & [26] \\
\hline \multirow{3}{*}{$\begin{array}{l}\text { ALG9-CDG (\# 608776); } \\
\text { ALG9 (NM_024740.2) }\end{array}$} & \multirow[t]{2}{*}{$\begin{array}{l}\text { c. } 1173+2 \mathrm{~T}>\mathrm{A},(\mathrm{p} . ?) \\
\text { homozygote; } \\
3 \text { pts (siblings) }\end{array}$} & \multirow{2}{*}{$\begin{array}{l}\text { severe skeletal dysplasia } \\
\text { [the authors proposed the name } \\
\text { Gilessen-Kaesbach-Nishimura } \\
\text { dysplasia for this severe form of } \\
\text { congenital disorder glycosylation] }\end{array}$} & $\begin{array}{l}\text { P1—-severe oligohydramnios and foetal biometry dated } \\
\text { the pregnancy to } 16 \text { weeks. } \\
\text { Pt 2-19 weeks of gestation - brachymelia, enlarged highly } \\
\text { echogenic kidneys with moderate hydronephrosis. } \\
\text { Pt 3-18 weeks of gestation - similar findings as in Pt } 2 .\end{array}$ & \multirow{2}{*}{$\begin{array}{l}\text { Pt } 1 \text {-At gestational age } 26+3 \text { weeks, } \\
\text { the mother went into spontaneous } \\
\text { labour, and the child was stillborn. } \\
\text { Pt } 2 \text {-Because of the severe kidney } \\
\text { disease, the family decided to terminate } \\
\text { the pregnancy at } 20+1 \text { weeks. } \\
\text { Pt } 3 \text { - The pregnancy was terminated at } \\
\text { 20 weeks. }\end{array}$} & \multirow[t]{2}{*}{ [29] } \\
\hline & & & $\begin{array}{l}\text { All-decreased ossification of the frontoparietal bones, } \\
\text { thickening of the occipital bones, deficient ossification of } \\
\text { cervical vertebral bodies and pubic bones, round pelvis } \\
\text { and short tubular bones with metaphyseal flaring. }\end{array}$ & & \\
\hline & $\begin{array}{l}\text { c.1588G > A (p.Glu530Lys) } \\
\text { homozygote; } \\
4 \text { pts }\end{array}$ & mild skeletal dysplasia & $\begin{array}{l}\text { Pt1-hip dislocation diagnosed at birth; } 6 \text { years-all } \\
\text { growth parameters were at the } 5 \text { th pc. Delayed bone age, } \\
\text { mesomelic brachymelia with thickening of frontal and } \\
\text { occipital bone, mild kyphosis of thoracolumbar spine, } \\
\text { bilateral hip dislocation, round pelvis, brachycephaly, and } \\
\text { shortening of greater sciatic notch. } \\
\text { Pt 2-3: mild skeletal dysplasia. } \\
\text { Pt 4-25-day-old boy-mild skeletal dysplasia. }\end{array}$ & Mild phenotype & [30] \\
\hline
\end{tabular}


Table 2. Cont.

\begin{tabular}{|c|c|c|c|c|c|}
\hline $\begin{array}{l}\text { CDG Type and Related Gene } \\
\text { (RefSeq) }\end{array}$ & Molecular Variant and Protein Change & Bone/Skeletal Manifestation & Clinical and Radiological Findings & Outcome & References \\
\hline \multirow{2}{*}{$\begin{array}{l}\text { ALG6-CDG (\# 603147); } \\
\text { ALG6 (NM_013339.4) }\end{array}$} & $\begin{array}{c}\text { c.257+5G > A, (p.?)/ } \\
\text { c.998C > T (p.Ala333Val) } \\
\text { compound heterozygote; } \\
1 \mathrm{pt}\end{array}$ & distal phalangeal hypoplasia & $\begin{array}{l}10 \text { weeks-large, open fontanel, brachytelephalangy of the } \\
\text { fingers } 2-5 \text {, shortening of the terminal phalanx of the } \\
\text { thumb, brachydactyly of the feet with missing ossification } \\
\text { of most of the middle and terminal phalanges, mild } \\
\text { metaphyseal flaring of the long bones of the lower } \\
\text { extremities and uneven ossification of the humerus. }\end{array}$ & Mild phenotype. & [31] \\
\hline & $\begin{array}{l}\text { c.897_899delAAT, (p.?)/ } \\
\text { c.494+2T > G, (p.?) } \\
\text { compound heterozygote; } \\
1 \mathrm{pt}\end{array}$ & distal phalangeal hypoplasia & $\begin{array}{l}\text { At birth-incomplete digits on hands and feet. } \\
\text { Bilateral reduction deformities of the distal phalanges of } \\
\text { digits II to IV in both hands, absence of the mid and distal } \\
\text { phalanges on digits II to IV in the feet. } \\
\text { Distal phalangeal hypoplasia with small tapering nails, } \\
\text { pointed distal digits, short distal phalanges and absent } \\
\text { middle phalanx on the left second digit. }\end{array}$ & Mild phenotype. & [32] \\
\hline \multirow{3}{*}{$\begin{array}{c}\text { PGM3-CDG (\# } \\
\text { 615816PGM3-CDG (\# 615816); } \\
\text { PGM3 (NM_001199917.2) }\end{array}$} & \multirow{2}{*}{$\begin{array}{c}\text { c.821A > G, (p.Asn274Ser) } \\
\text { homozygote; } \\
1 \mathrm{pt}(\mathrm{Pt} 1) \\
\text { c.821dup (p.Asn274Lysfs*7)/c.1436A > G } \\
(\mathrm{p} . \text { Gln479Arg) } \\
\text { compound heterozygote; } \\
1 \mathrm{pt}(\mathrm{Pt} 2)\end{array}$} & \multirow{2}{*}{$\begin{array}{l}\text { severe skeletal dysplasia with } \\
\text { radiographic pattern of Desbuquois } \\
\text { dysplasia }\end{array}$} & $\begin{array}{l}\text { Pt } 1 \text {-at birth: rhizomelic shortening of tubular bones with } \\
\text { brachydactyly, short metacarpal and metatarsal bones and } \\
\text { phalanges, and pectus carinatum. Bilateral exaggerated } \\
\text { trochanter minor, coronal clefts of the caudal lumbar } \\
\text { vertebrae, and cranial Wormian bones. }\end{array}$ & $\begin{array}{l}\text { Pt1—At } 4 \text { months of age received a } \\
\text { hematopoietic stem cell transplant } \\
\text { (HSCT). She was globally } \\
\text { developmental delayed (4-month stage } \\
\text { at } 1 \text { year of age). }\end{array}$ & \multirow[b]{2}{*}{ [33] } \\
\hline & & & $\begin{array}{l}\text { Pt 2-fetal ultrasound-short limbs, small thoracic } \\
\text { diameter. After birth—short-limbed dwarfism, } \\
\text { brachydactyly, pectus carinatum. Short tubular bones, } \\
\text { several phalangeal and tarsal dislocations, short femoral } \\
\text { necks with metaphyseal beaking, and exaggerated lesser } \\
\text { trochanters. }\end{array}$ & $\begin{array}{l}\text { Pt 2-the most severe } \\
\text { phenotype-complex neurological } \\
\text { deterioration and died at } 7 \text { months of } \\
\text { age from overwhelming infection. }\end{array}$ & \\
\hline & $\begin{array}{l}\text { c.1219T > C (p.Phe407Leu) } \\
\text { homozygote; } \\
2 \mathrm{pts} \\
\text { The available evidence is currently insufficient to } \\
\text { determine the role of this variant in disiase. } \\
\text { Therefore, it has been classified as a Variant of } \\
\text { Uncertain Significance [ClinVar Version: } \\
\text { 15-Jun-2021]. }\end{array}$ & $\begin{array}{l}\text { severe skeletal dysplasia with } \\
\text { radiographic pattern of Desbuquois } \\
\text { dysplasia }\end{array}$ & 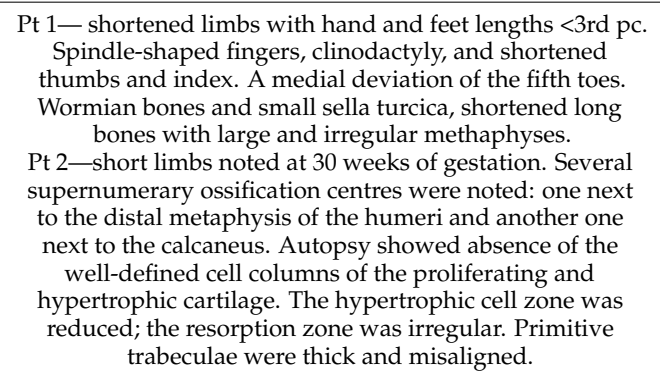 & $\begin{array}{l}\text { Pt } 1 \text {-died } 7 \text { days after birth of } \\
\text { respiratory insufficiency and } \\
\text { pulmonary hypertension. }\end{array}$ & {$[36]$} \\
\hline
\end{tabular}


Table 2. Cont

\begin{tabular}{|c|c|c|c|c|c|}
\hline $\begin{array}{l}\text { CDG Type and Related Gene } \\
\text { (RefSeq) }\end{array}$ & Molecular Variant and Protein Change & Bone/Skeletal Manifestation & Clinical and Radiological Findings & Outcome & References \\
\hline $\begin{array}{l}\text { B3GAT3-CDG (\# 245600); } \\
\text { B3GAT3 (NM_012200.4) }\end{array}$ & 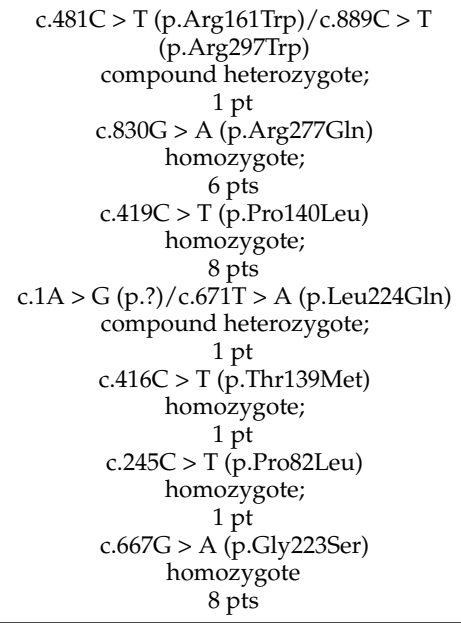 & variable skeletal anomalies & $\begin{array}{l}\text { Among } 26 \text { described cases-wide phenotypic range, } \\
\text { including: short stature }(18 / 23) \text {, multiple fractures } 8 / 18 \text {, } \\
\text { kyphoscoliosis }(8 / 24) \text {, peculiar fingers }(25 / 25), \text { foot } \\
\text { deformity }(22 / 25), \text { pectus excavatum/carinatum }(3 / 19) \text {, } \\
\text { bowing of limbs }(5 / 19) \text {, low bone density/osteopenia } \\
(10 / 11), \text { platyspondyly }(1 / 20), \text { radioulnar synostosis } \\
(11 / 13), \text { metaphyseal flaring }(3 / 5) \text {, iliac abnormalities } \\
(2 / 4) \text {, radial head subluxation or dislocation }(3 / 5) \text {. }\end{array}$ & n.a. & [49] \\
\hline \multirow{2}{*}{$\begin{array}{l}\text { SLC35D1-CDG (\# 269250); } \\
\text { SLC35D1 (NM_015139.3) }\end{array}$} & \multirow{2}{*}{$\begin{array}{l}\text { c.125delA, (p.Ser42fs*9) } \\
\text { homozygote; } \\
1 \mathrm{pt}(\mathrm{Pt} 1) \\
\text { c.932G }>\text { A, (p.Trp311*)/ } \\
\text { c.636 + } 1 \mathrm{G}>\mathrm{T},(\mathrm{p} . ?) \\
\text { compound heterozygote; } \\
1 \mathrm{pt}(\mathrm{Pt} 2)\end{array}$} & \multirow{2}{*}{ Schneckenbecken dysplasia } & $\begin{array}{l}\text { Pt 1: } 20 \text { weeks of gestation-severe hydrops, extremely } \\
\text { short extremities, small thorax. Radiographs showed } \\
\text { typical findings for Schneckenbecken dysplasia, including } \\
\text { small ilia with snail-like appearance, platyspondylia with } \\
\text { oval vertebral bodies and general shortness of long bones } \\
\text { with dumbbell-like appearance. The chondroosseous } \\
\text { morphology was also typical for Schneckenbecken } \\
\text { dysplasia. Hypercelluluar cartilage with scare extra-cellular } \\
\text { matrices and absence of columnar alignment of } \\
\text { proliferating chondrocytes. }\end{array}$ & $\begin{array}{l}\text { Pt } 1 \text {-Termination of pregnancy at } 22 \\
\text { weeks. }\end{array}$ & \multirow{2}{*}{ [43] } \\
\hline & & & $\begin{array}{l}\text { Pt 2: At birth-hydrops, narrow chest, the limbs were very } \\
\text { short in all segments with bilateral clubfeet. Radiographs } \\
\text { showed features typical of Schneckenbecken dysplasia. } \\
\text { The ilia were short with a snail-like appearance and a } \\
\text { flattened acetabular roof. The long bones were short and } \\
\text { the metaphyses were abnormally wide. The spine was } \\
\text { abnormal, with inter-pedicular narrowing, particularly in } \\
\text { the lumbar region. }\end{array}$ & $\begin{array}{l}\text { Pt } 2 \text { died of respiratory insufficiency in } \\
\text { the immediate neonatal period. }\end{array}$ & \\
\hline
\end{tabular}


Table 2. Cont.

CDG Type and Related Gene (RefSeq)

Molecular Variant and Protein Change

Bone/Skeletal Manifestation

Clinical and Radiological Findings

Pt 1: 6 months-growth retardation;

1 year-remarkable joint laxity; 2 years-head

circumference at 3rd pc, weight and height significantly

below the 3rd pc. Her

finger pads and lax interphalangeal joints. She had an

interrupted single transverse palmer crease, lax wrists,

prominent pads and partial syndactyly of 3 rd and 4 th toes

prominent pads an ing toes.

Skeletal survey demonstrated bilateral proximal

radioulnar synostosis and bowing of the shafts of the

radius and ulna. The clavicles were short with broad
medial ends. There was anterior splaying of ribs,

bnormal appearance of distal metaphyses of the humeri

and ulnae, cone shaped appearance of distal phalanx of first toe, and diffuse osteopenia.

skeletal and joint abnormalities

Pt 2: 33 years-head circumference at $3 \mathrm{rd} \mathrm{pc}$, weight at $3 \mathrm{rd}$

pc, height $<3$ rd pc. Lax joints, loose skin, and limited

movement of elbow joints were observed. His fingers were

had bilateral equinovarus deformities and there were

many atrophic scars on the sides of his feet and back of his

leos and hips Skeletal $X$-rays demonstrated findings

similar to those of Pt1 in particular to the proxima

radioulnar synostosis bilaterally.
44GALT7-CDG (\# 130070);

Outcome

References 
Table 2. Cont

\begin{tabular}{|c|c|c|c|c|c|}
\hline $\begin{array}{l}\text { CDG Type and Related Gene } \\
\text { (RefSeq) }\end{array}$ & Molecular Variant and Protein Change & Bone/Skeletal Manifestation & Clinical and Radiological Findings & Outcome & References \\
\hline & $\begin{array}{l}\text { c.792 + 182G > A (p.?) } \\
\text { homozygote; } \\
3 \text { pts (Pt 1-3) }\end{array}$ & skeletal dyplasia & $\begin{array}{l}\text { Pt1-Birth weight } 3250 \mathrm{~g} \text { (50th pc), length } 50 \mathrm{~cm} \text { (25th pc), } \\
\text { head circumference } 36 \mathrm{~cm} \text { ( } 50 \text { th pc). } \\
11 \text { years - short stature (but normal head growth rate), } \\
\text { generalized epi-metaphyseal dysplasia and joint } \\
\text { destruction diagnosed as Desbuquois syndrome; pectus } \\
\text { carinatum, dorsolumbar kyphosis and severe } \\
\text { sinistroconvex scoliosis, short distal phalanges, genua } \\
\text { vara, pedes planovalgi, joint hyperlaxity; osteoporosis and } \\
\text { important epi- and metaphyseal dysplasia with broad } \\
\text { metaphyses, irregular epiphyses, and thin bone cortex. } \\
\text { The vertebrae were flattened and beaked and the } \\
\text { phalanges were broad. } \\
\text { Pt2-5 months-absent second-toe nails, joint hyperlaxity, } \\
\text { right hip dysplasia. }\end{array}$ & n.a. & {$[6,50]$} \\
\hline $\begin{array}{l}\text { TMEM165-CDG (\# 614727); } \\
\text { TMEM165 (NM_018475.5) }\end{array}$ & $\begin{array}{c}\text { c.377G > A (p.Arg126His) } \\
\text { homozygote; } \\
1 \mathrm{pt}(\mathrm{Pt} 4) \\
\text { c.376C > T (p.Arg126Cys)/c.910G > A } \\
\text { (p.Gly304Arg) } \\
\text { compound heterozygote; } \\
1 \text { pt (Pt 5) }\end{array}$ & skeletal dyplasia & $\begin{array}{l}\text { Generalized osteoporosis, discrete irregular metaphyses of } \\
\text { the long bones, discrete plathyspondyly, broad iliac wings, } \\
\text { horizontal acetabular roofs, and subluxation of the right } \\
\text { femur. } \\
\text { Pt 3-birth weight of } 3360 \mathrm{~g}(25 \mathrm{th} \text { pc) and length of } 49 \mathrm{~cm} \\
\text { (between } 3 \mathrm{rd} \text { and } 10 \mathrm{cth} \text { pc). } \\
6 \text { years-body length-7 SDS but head circumference } \\
\text { normal ( } 49.9 \mathrm{~cm}, 25 \mathrm{th} \text { pc). Radiology of the skeleton at age } \\
1 \text { year revealed generalized osteopenia, a J-like sella } \\
\text { turcica, hypoplasia of the skull base, mild anterior beaking } \\
\text { of vertebrae D11, D12, L1, and L2, broad radial and unar } \\
\text { metaphyses, strongly underdeveloped carpal bones, } \\
\text { plump and broad phalanges, horizontal acetabula, very } \\
\text { discrete opacification of the right proximal femur } \\
\text { epiphysis, no ossification of the left proximal femur } \\
\text { epiphysis, broad proximal femur metaphyses, broad } \\
\text { metaphyses and strongly underdeveloped distal femoral } \\
\text { and proximal tibial epiphyses. } \\
\text { Pt } 4-9 \text { years-normal growth, mild rhizomelia, no clear } \\
\text { skeletal anomalies. } \\
\text { Pt } 5 \text { - short stature, dysplastic toenails, osteoporosis, } \\
\text { anterior beaking of lumbal vertebrae, dysplastic vertebrae } \\
\text { and ribs, dysplastic fourth metacarpals and metatarsals, } \\
\text { hypoplasia of femoral heads, and kyphoscoliosis. }\end{array}$ & n.a. & {$[6,50]$} \\
\hline
\end{tabular}


Table 2. Cont

\begin{tabular}{|c|c|c|c|c|c|}
\hline $\begin{array}{l}\text { CDG Type and Related Gene } \\
\text { (RefSeq) }\end{array}$ & Molecular Variant and Protein Change & Bone/Skeletal Manifestation & Clinical and Radiological Findings & Outcome & References \\
\hline \multirow[t]{2}{*}{$\begin{array}{l}\text { COG7-CDG (\# 608779); } \\
\text { COG7 (NM_153603.4) }\end{array}$} & $\begin{array}{c}\text { c.169+4A > C (p.?) } \\
\text { homozygote; } \\
3 \text { pts }\end{array}$ & variable skeletal anomalies & $\begin{array}{l}\text { Pt 1-At birth-Weight } 2645 \mathrm{~g}(15 \mathrm{th} \text { pc), length } 44 \mathrm{~cm} \\
\text { (<3rd pc), head circumference } 31.5 \mathrm{~cm}(<3 \mathrm{rd} \mathrm{pc}) \text {. Adducted } \\
\text { thumbs, overlapping, long fingers, a simian crease, } \\
\text { contractures of the PIP and DIP joints with ulnar deviation } \\
\text { of the hands were observed. } \\
\text { Pt } 2 \text {-At birth-Weight } 2890 \mathrm{~g}(25 \mathrm{th} \text { pc), length } 42 \mathrm{~cm} \\
(<3 \mathrm{rd} \mathrm{pc}) \text {, head circumference } 33.5 \mathrm{~cm}(10 \text { thpc). Adducted } \\
\text { thumbs, a simian crease, overlapping fingers with } \\
\text { contractures of the PIP joints and ulnar deviation of the } \\
\text { hands were observed. } \\
\text { Pt 3-at birth-Weight } 2300 \mathrm{~g}(<3 \mathrm{rd} \text { pc), length } 41 \mathrm{~cm} \\
\text { (<3rd pc), head circumference } 31.9 \mathrm{~cm}(<3 \mathrm{rd} \text { pc). Adducted } \\
\text { thumbs and overlapping, long toes and fingers were } \\
\text { observed. }\end{array}$ & $\begin{array}{l}\mathrm{Pt} 1 \text { died at the age of } 9 \text { months. } \\
\mathrm{Pt} 2 \text { died at the age of } 7 \text { months. } \\
\mathrm{Pt} 3 \text { died at the age of } 8 \text { months. }\end{array}$ & [37] \\
\hline & $\begin{array}{c}\text { c.169+4A > C (p.?)/ } \\
\text { homozygote; } \\
2 \text { pts }\end{array}$ & variable skeletal anomalies & $\begin{array}{l}\text { X-ray of Pt } 1 \text { lacked humerus and tibia epiphysis; } \\
\text { Pt } 2 \text { had shoer extremities. }\end{array}$ & Died at 5 and 10 weeks, respectively & [38] \\
\hline $\begin{array}{l}\text { COG1-CDG (\# 611209) } \\
\text { COG1 (NM_018714.3) }\end{array}$ & $\begin{array}{c}\text { c.2665dup (p.Arg889Profs*12) } \\
\text { homozgote; } \\
1 \mathrm{pt}\end{array}$ & variable skeletal anomalies & $\begin{array}{c}2 \text { months and } 3 \text { weeks-small hands and feet; } \\
7 \text { months-growth retardation with a rhizomelic short } \\
\text { stature; } \\
15 \text { months-growth below the } 5 \text { th percentile, head } \\
\text { circumference followed the 5th percentile, progressive } \\
\text { microcephaly; } \\
\text { Rib fusions, rib abnormalities, vertebral abnormalities } \\
\text { were observed. }\end{array}$ & Last follow-up at 21 months of age & [39] \\
\hline $\begin{array}{l}\text { COG8-CDG (\# 611182); } \\
\text { COG8 (NM_022341.2) }\end{array}$ & $\begin{array}{c}\text { c.1611C > G (p.Tyr537*) } \\
\text { homozygote; } \\
1 \mathrm{pt}\end{array}$ & variable skeletal anomalies & $\begin{array}{l}3 \text { years: Small hands and feet, Hypoplasia of the first } \\
\text { phalanx of some fingers and toes, Wide space between the } \\
\text { first and second toes, Clinodactily of the third and fourth } \\
\text { toes, acquired microcephay from } 4 \text { years of age. }\end{array}$ & $\begin{array}{l}\text { From the age of } 7 \text {, her cerebellar ataxia } \\
\text { has worsened. }\end{array}$ & [40] \\
\hline
\end{tabular}


Table 2. Cont

\begin{tabular}{|c|c|c|c|c|c|}
\hline $\begin{array}{l}\text { CDG Type and Related Gene } \\
\text { (RefSeq) }\end{array}$ & Molecular Variant and Protein Change & Bone/Skeletal Manifestation & Clinical and Radiological Findings & Outcome & References \\
\hline \multirow{4}{*}{$\begin{array}{l}\text { PMM2-CDG (\# 212065); } \\
\text { PMM2 (NM_000303.3) }\end{array}$} & $\begin{array}{c}\text { c.691G > A (p.Val231Met) / } \\
\text { c.442G > A (p.Asp148Asn) } \\
\text { compound heterozygote; } \\
1 \text { pt }\end{array}$ & $\begin{array}{l}\text { radiographic skeletal appearances } \\
\text { were consistent with a primary } \\
\text { skeletal dysplasia closest to Kniest } \\
\text { dysplasia (OMIM 156550) or } \\
\text { spondyloepiphyseal dysplasia } \\
\text { congenita (OMIM 183900) (type II } \\
\text { collagen disorders). }\end{array}$ & $\begin{array}{l}\text { Obstetric ultrasound examination revealed macrocephaly } \\
\text { with shortened long bones (femur length <5th pc), lumbar } \\
\text { lordosis; } \\
\text { Neonatal period-short long bones with, dumbbell" } \\
\text { metaphyseal expansions, generalized epiphyseal } \\
\text { ossification delay, ovoid and anteriorly beaked vertebral } \\
\text { bodies, hypoplastic cervical vertebrae, hypoplastic pubic } \\
\text { bones, and bullet-shaped short tubular bones; } \\
\text { Cervical spine MRI: elevation of the posterior arch of C1 } \\
\text { with the occipital bone and significant spinal canal } \\
\text { stenosis at the craniocervical junction due to a bone spur }\end{array}$ & n.a. & [7] \\
\hline & n.a. & osteopenia & $\begin{array}{l}3 \text { pts aged } 14-27 \text { years: Low bone density. } \\
\text { Common clinical findings are skeletal changes including } \\
\text { peculiar thoracic deformity and joint restriction, while a } \\
\text { major radiological feature is diffuse osteopenia. }\end{array}$ & n.a. & [17] \\
\hline & n.a. & variable skeletal anomalies & $\begin{array}{l}2 \text { months-pectus excavatum, restricted extension of } \\
\text { knees and elbows, and long fingers with camptodactyly. } \\
\text { Diffuse osteopenia, disturbed modeling of bones: anterior } \\
\text { widening of the ribs, thick clavicles, dorsolumbar kyphosis } \\
\text { with slight hook-like dysplasia of the antero-inferior } \\
\text { border of the first lumbar vertebrae. squared and flared } \\
\text { iliac wings, horizontal acetabular roofs, and poorly formed } \\
\text { and thickened ischial and pubic bones. }\end{array}$ & n.a. & [18] \\
\hline & n.a. & variable skeletal anomalies & $\begin{array}{l}\text { Bone-in-bone appearance of the skeleton, with flaring of } \\
\text { the iliac wings and sloping acetabular roof. }\end{array}$ & n.a. & [20] \\
\hline $\begin{array}{c}\text { PIGV-CDG } \\
\text { PIGV (NM_017837.4) }\end{array}$ & $\begin{array}{c}\text { c.467G > A (p.Cys156Tyr) } / \mathrm{c} .1022 \mathrm{C}>\mathrm{A} \\
\text { (p.Ala341Glu) } \\
\text { compound heterozygote; } \\
1 \mathrm{pt}(\mathrm{Pt} 1) \\
\text { c.1022C > A (p.Ala341Glu) } \\
\text { homozygote; } \\
1 \text { pt (Pt 2) }\end{array}$ & $\begin{array}{l}\text { variable skeletal anomalies including } \\
\text { brachtelephalangy }\end{array}$ & 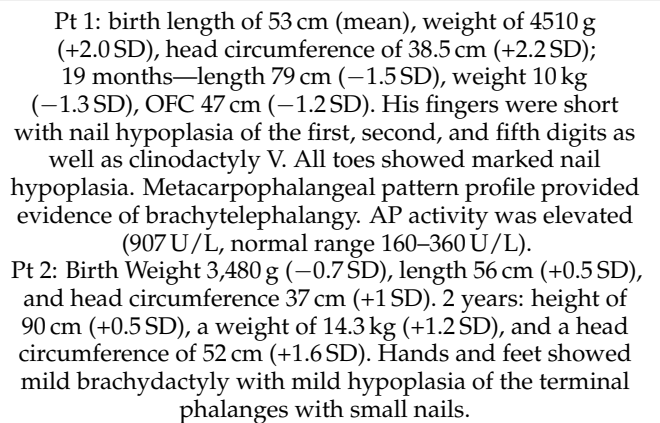 & n.a. & [52] \\
\hline
\end{tabular}
phalanges with small nails. 
Table 2. Cont

\begin{tabular}{|c|c|c|c|c|c|}
\hline $\begin{array}{l}\text { CDG Type and Related Gene } \\
\text { (RefSeq) }\end{array}$ & Molecular Variant and Protein Change & Bone/Skeletal Manifestation & Clinical and Radiological Findings & Outcome & References \\
\hline $\begin{array}{c}\text { PIGL-CDG } \\
\text { PIGL (NM_004278.4) }\end{array}$ & $\begin{array}{c}\text { c.60G > A }(\text { p.Trp20*) } / \mathrm{c} .262 \mathrm{C}>\mathrm{T}(\mathrm{p} . \operatorname{Arg} 88 \mathrm{Cys}) \\
\text { compound heterozygote } \\
1 \mathrm{pt}\end{array}$ & $\begin{array}{l}\text { variable skeletal anomalies including } \\
\text { brachtelephalangy }\end{array}$ & $\begin{array}{l}\text { Birth weight } 2665 \mathrm{~g} \text { (5th pc), OFC } 32 \mathrm{~cm} \text { ( } 5 \text { th pc); } 4 \text { years: } \\
\text { growth parameters were normal with weight, height and } \\
\text { head circumference on the } 75 \text { th pc. Mild pectus excavatum } \\
\text { and clinodactyly involving the fifth digits, } 4 \text { th and } 5 \text { th toes } \\
\text { bilaterally. } \\
\text { X-ray hands showed deformity of the middle phalanx of } \\
\text { the } 5 \text { th finger bilaterally with the lateral aspect of the } \\
\text { phalanx being shorter than the medial aspect. }\end{array}$ & n.a. & [53] \\
\hline \multirow{2}{*}{$\begin{array}{c}\text { PIGO-CDG } \\
\text { PIGO (NM_032634.4) }\end{array}$} & $\begin{array}{c}\text { c.2869C > T(p.Leu957Phe) / } \\
\text { c.2361dup (p.Thr788Hisfs*5) } \\
\text { compound heterozygote; } \\
2 \text { pts (Pt 1,2) } \\
\text { c.2869C }>\text { T (p.Leu957Phe) / } \\
\text { c.3069 + 5G > A (p.?) } \\
\text { compound heterozygote; } \\
1 \text { pt (Pt 3) }\end{array}$ & \multirow{2}{*}{$\begin{array}{l}\text { variable skeletal anomalies including } \\
\text { brachytelephalangy }\end{array}$} & 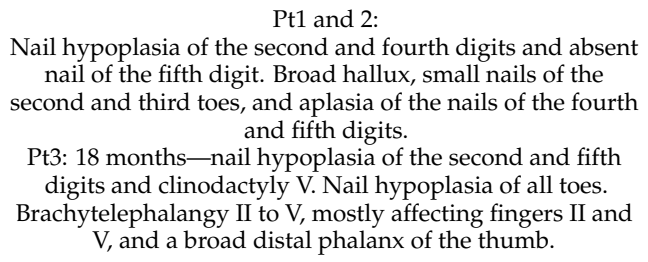 & n.a. & [58] \\
\hline & $\begin{array}{c}\text { c.2612A > C (p.His871Pro)/ } \\
\text { c.1810dupC (p.Arg604Profs*40) } \\
\text { compound heterozygote } \\
1 \text { pt }\end{array}$ & & $\begin{array}{l}\text { Birth weight } 2870 \mathrm{~g} \text {, length unknown, head circumference } \\
36.5 \mathrm{~cm} \text {. Hypoplastic toenails at birth. } \\
7 \text { years: height } 123 \mathrm{~cm} \text { (SDS 0.0), weight } 25.5 \mathrm{~kg} \text { (SDS 0.6), } \\
\text { head circumference } 56 \mathrm{~cm} \text { (SDS } 2.5) \\
\text { mild camptodactyly of the fingers, and small hands and } \\
\text { feet with short fingers and toes. } \\
\text { Radiological examination of the skeleton showed a thin } \\
\text { cortex, triangular distal toe phalanges, scoliosis. }\end{array}$ & n.a. & [59] \\
\hline
\end{tabular}




\subsection{Skeletal Dysplasia in Other CDGs}

Contrary to PMM2-CDG, skeletal dysplasia was well characterized in other CDGs, including ALG12-CDG, ALG3-CDG, ALG9-CDG, ALG6-CDG, PGM3-CDG, CSGALNACT1CDG, SLC35D1-CDG and TMEM165-CDG (Table 1).

The combination of features observed in patients with ALG12-CDG, including interphalangeal dislocations, talipes equinovarus, rhizomelic limb shortening, midface hypoplasia, short metacarpals, and a horizontal acetabular roof, resembled the features of pseudodiastrophic dysplasia (Table 1) [21,22]. Pseudodiastrophic dysplasia (264180) is characterized by rhizomelic shortening of the limbs and severe clubfoot deformity, in association with elbow and proximal interphalangeal joint dislocations, platyspondyly, and scoliosis [23-25].

The features of patients with ALG9-CDG reported by Tham et al. were similar to those reported by Gillessen-Kaesbach and Nishimura and to some extent overlapping with those of individuals with ALG3-CDG and ALG12-CDG (Table 1 and 2) [27-30].

Most patients affected with PGM3-CDG showed skeletal abnormalities (Tables 1 and 2). Scoliosis has been reported as the mildest manifestation of the PGM3-related skeletal phenotype [33]. Two patients described by Stray-Pedersen et al. (2014) presented with a recognizable skeletal dysplasia resembling Desbuquois dysplasia (\#251450) [34]. This condition is an autosomal recessive osteochondrodysplasia characterized by severe prenatal and postnatal growth retardation (stature less than $-5 \mathrm{SD}$ ), short extremities (rhizomelic and mesomelic shortening), shortened tubular bones with metaphyseal flaring, an exaggerated trochanter minor of the proximal femur (monkey-wrench malformation), advanced bone age, joint laxity, and progressive kyphoscoliosis (Table 2) [35,36].

Skeletal dysplasia was also reported as the main clinical feature of patients with COG7CDG, COG1-CDG and COG8-CDG (Table 1). While patients with COG8-CDG displayed severe skeletal dysplasia, COG1-CDG and COG8-CDG patients had a significantly milder clinical presentation (Table 2) [37-40].

\subsection{Joint and Cartilage Involvement in CDG}

In two patients with typical Schneckenbecken dysplasia (\# 269250), Rautengarten et al. found biallelic mutations in both alleles of SLC35D1 (Tables 1 and 2) [43]. Schneckenbecken dysplasia (\#269250) is a perinatally lethal skeletal dysplasia characterized by the distinctive, snail-like appearance of the ilia, thoracic hypoplasia, severe flattening of the vertebral bodies and short, thick long bones [44].

Among genes implicated in Ehlers-Danlos syndrome (EDS), biallelic mutations in B4GALT7 (encoding galactosyltransferase-I) have been described in patients affected with the progeroid form of EDS presenting with radioulnar synostosis, diffuse osteopenia, splaying of the ribs, broad thumbs and long fingers, long and overriding toes, equinovarus deformities, single palmar crease, and hypermobile joints (Tables 1 and 2) [45-48].

Short stature, generalized osteopenia/osteoporosis and epi- and metaphyseal dysplasia were reported in patients with TMEM165-CDG (Table 1) [6,50].

\subsection{GPI-Biosynthesis Defects (GPI-BD)}

Defects in the glycosylphosphatidylinositol (GPI) biosynthesis pathway have unique skeletal manifestations. GPI-anchor biosynthesis can be divided into the synthesis stage (responsible genes: DPM1, DPM2, DPM3, MPDU1, PIGA, PIGB, PIGC, PIGF, PIGG, PIGH, PIGL, PIGM, PIGN, PIGO, PIGP, PIGQ, PIGV, PIGW, PIGX, PIGY) and the transamidase + remodelling stage (responsible genes: GPA1, MPPE1, PGAP1, PGAP2, PGAP3, PIGK, PIGS, PIGT, PIGU) [51]. Abnormal digit morphology, absent distal phalanges, aplasia/hypoplasia of fingers, short digit, broad finger and broad toe, clubbing, and clinodactyly were more frequently observed in the synthesis group (Table 1) [52-57]. On the other hand, osteopenia was more frequently observed in the transamidase + remodelling group [53].

Brachytelephalangy was consistently found in all the reported PIGV-CDG patients (Table 2) [52]. It was also found in most of the reported patients with PIGO-CDG (Hyper- 
phosphatasia with mental retardation syndrome 2, HPMRS2, \#614749) [58,59]. This skeletal finding could lead to the suspicion of Coffin-Siris syndrome given the neurological findings in both syndromes, i.e., delayed psychomotor development, hypotonia and expressive language delay. Coffin-Siris syndrome in its typical form (CSS1, \#135900) characterized by aplasia or hypoplasia of the distal phalanx and hypoplastic, aplastic nails (even absent fifth fingernail in some patients), developmental or cognitive delay of varying degree, distinctive facial features, hypotonia, hirsutism/hypertrichosis, and congenital malformations of the cardiac, gastrointestinal, genitourinary, and/or central nervous systems [60].

\subsection{Genotype-Phenotype Correlation}

The genetic background of CDG is highly variable and includes various genes. In Table 2, we report the clinical and molecular findings of CDG patients with skeletal abnormalities. Most of patients were compound heterozygotes for autosomal recessive hypomorphic mutations and homozygotes are rather sporadic or family related cases. It is difficult to draw any strong conclusions regarding the possible genotype-phenotype correlation in such a heterogenic group.

For patients with homozygous mutations, we were able to give some conclusions regarding, i.e., CSGALNACT1 and SLC35D1 genes. Knockout of the orthologous mouse CSGALNACT1 indicates that the protein is necessary for normal cartilage development and aggrecan metabolism [61]. Mutations in CSGALNACT1 are associated with a mild skeletal dysplasia and joint laxity [41]. The clinical significance of the described variant c.791A > G (p.Asn264Ser) is defined as likely pathogenic.

Hiraoka et al. created Slc35d1-deficient mice that present with a lethal form of skeletal dysplasia (severe shortening of limbs and facial structures) with short, sparse chondroitin sulphate chains caused by a defect in chondroitin sulphate biosynthesis [62]. Epiphyseal cartilage in these homozygous mutant mice showed a decreased proliferating zone with round chondrocytes, scarce matrices and reduced proteoglycan aggregates. Variant c.125delA in SLC35D1 was reported only once, and its significance has been defined as pathogenic (https: / / www.ncbi.nlm.nih.gov / clinvar/RCV000001182, accessed on 27 June 2021).

Skeletal and/or bone mineral density abnormalities are common features of all CDG types. Osteoporosis and/or osteopenia, growth failure, skeletal dysplasia and joint abnormalities were described (Tables 1 and 2). Genotype-phenotype correlation is impossible due to gene heterogeneity, diversity of individual markers and compound heterozygosity in most described cases (Table 2).

Contrary to PMM2-CDG, skeletal abnormalities are well characterized in other CDG. There is a group of CDGs, including ALG12-CDG, ALG3-CDG, ALG9-CDG, ALG6-CDG, PGM3-CDG, CSGALNACT1-CDG, SLC35D1-CDG, and TMEM-165 with well-defined skeletal dysplasia. In some of them (ALG12-CDG, ALG3-CDG, ALG9-CDG, PGM3-CDG, SLC35D1-CDG), a severe prenatal-onset skeletal dysplasia was observed and associated with an early death. Among them, ALG12-CDG, ALG3-CDG and ALG9-CDG represent distinct entities involved in primary lipid-linked oligosaccharide (LLO) synthesis. These three mannosyltransferases function in direct sequential order, adding mannose moieties to LLO. On the other hand, phosphoglucomutase 3 (PGM3) is required for the biosynthesis of uridine diphosphate $N$-acetylglucosamine (UDP-GlcNAc), a precursor for both $N$-linked and $O$-linked glycosylated proteins. These facts could explain the severe phenotype of reported skeletal abnormalities.

Glycosylation is essential for proteins involved in the development of cartilage and bone and in skeletal patterning pathways. Two of the glycosylation defects, TMEM165-CDG and CSGALNACT1-CDG, are characterized by skeletal dysplasia and abnormal cartilage development. It has been also observed in an experimental study by Bammens et al. (2015), that the TMEM165-deficient zebrafish model exhibited phenotypic patterns of bone dysplasia and abnormal cartilage development similar to the major clinical findings reported in three patients with a homozygous splice mutation [63]. 
Two other CDGs, CSGALNACT1-CDG and SLC35D1-CDG, are caused by defects in genes responsible for glycosaminoglycans biosynthesis.

CSGalNAcT1 (chondroitin sulphate $N$-acetylgalactosaminyltransferase-1) gene codes the CSGalNAcT-1 protein that is the main enzyme in the biosynthesis of sulphated glycosaminoglycans chondroitin and dermatan sulphate in cartilage [42]. Biallelic loss-offunction mutations in CSGALNACT1 gene results in reduced CSGalNAcT-1 activity leading to altered levels of chondroitin, dermatan, and heparan sulphate and cause a mild skeletal dysplasia with joint laxity and advanced bone age, CSGALNACT1-CDG [42].

Another gene, SLC35D1 gene, encodes the protein that transports substrates needed for glucuronidation and chondroitin sulphate biosynthesis [62]. The protein resides in the endoplasmic reticulum, and transports both UDP-glucuronic acid and UDP-Nacetylgalactosamine from the cytoplasm to the endoplasmic reticulum. In humans, loss of function mutation in this gene cause Schneckenbecken dysplasia associated with perinatal lethal skeletal dysplasias [62].

\subsection{Risk Factors for Osteoporosis in CDGs}

Hormonal dysfunction, resulting from hypogonadotrophic hypogonadism, is a risk factor for reduced bone mineral density in females with CDGs $[7,64,65]$. It requires treatment with oestrogen to avoid osteoporosis; however, it increases the risk of thrombotic events and must be dosed carefully.

Gastrointestinal problems and malabsorption may lead to hypovitaminosis D. It is therefore worth considering screening for common causes of chronically decreased vitamin D such as celiac disease [65].

Bone deformities and chronic pain result in limited mobility and wheelchair use. Low BMI and disuse sarcopenia are frequent clinical features of patients with CDGs and, in the long term, they may cause low bone mineral density and recurrent fractures.

\subsection{Bone Markers}

Historically, this GPI-linked enzyme, has been used to assign glycosylphosphatidylinositol biosynthesis defects (GPI-BD) to the phenotypic group termed hyperphosphatasia with mental retardation syndrome (HPMRS) and to distinguish them from another subset of GPI-BD-multiple congenital anomalies hypotonia seizures syndrome (MCAHS) [51]. However, with the increasing number of individuals diagnosed with a GPI-BD, hyperphosphatasia has been shown to be a variable feature and not more useful for GPI-BD distinguishing.

Bone-specific alkaline phosphatase activity measured in serum is an indicator of osteoblastic activity.

Serum and urinary deoxypyridinoline and pyridinoline, cross-linking amino acids that stabilize collagen chains within the extracellular matrix, can also be measured when screening for reduced bone mineral density in PMM2-CDG disorders [10]. Bone markers of formation (P1NP) or resorption (CTX) measurement in CDGs requires further clinical studies to better understand what factors are likely to affect their concentration in these conditions. All the bone markers should be interpreted in the context of symptoms, age, gender, limited physical activity including wheelchair use, and diet.

Transferrin glycosylation has been the main biomarker for CDG screening and monitoring of the response to treatment. The analysis of protein $\mathrm{N}$-glycosylation profile is widely used in CDGs and other conditions [66].

There is a scope for using $\mathrm{N}$-glycans in monitoring of bone disease progression and further research is warranted to confirm the preliminary findings [67].

The effectiveness of supportive management can be evaluated by DEXA scan (Figure 3), a gold standard method for monitoring the progression of bone mineral density decline. The whole spine x-ray (Figure 2) can be used for identification of bone deformities and fractures. QCT however is the sensitive quantitative method used to assess the bone mineral density. 
Body composition has become increasingly utilized in Inherited Metabolic Disorders field and provides additional information about the bone and muscle involvement.

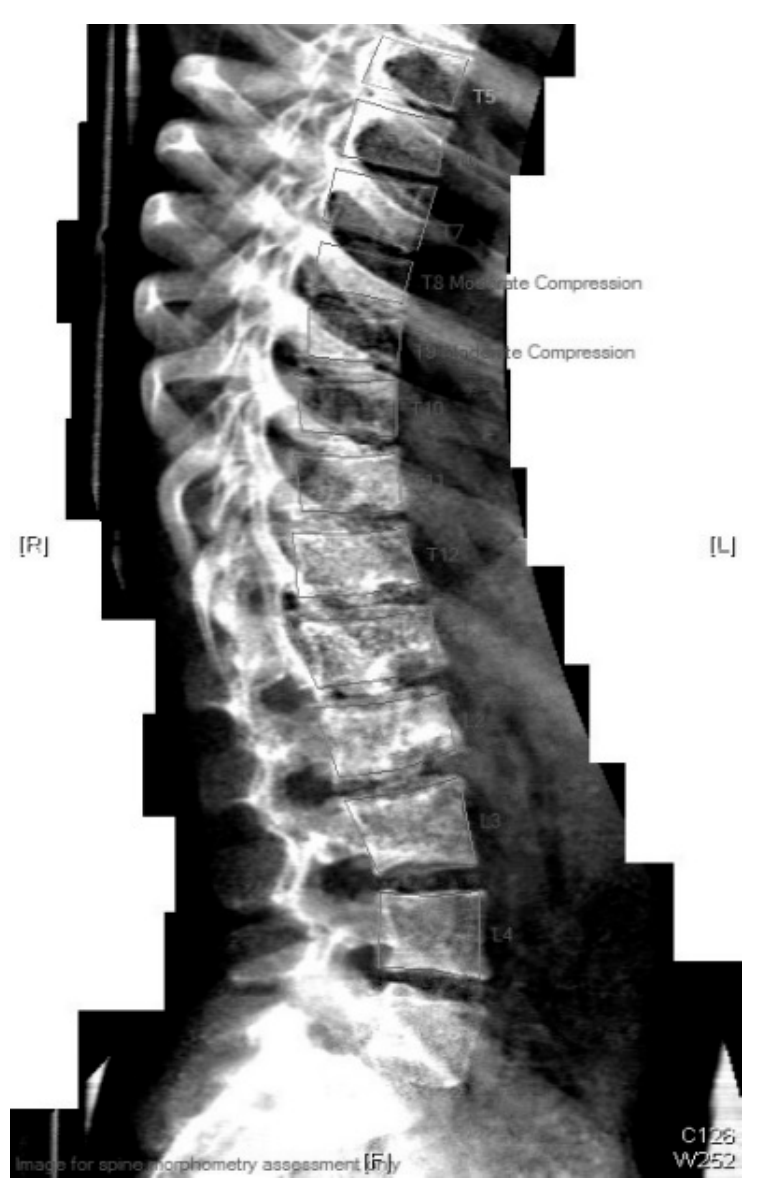

(a)

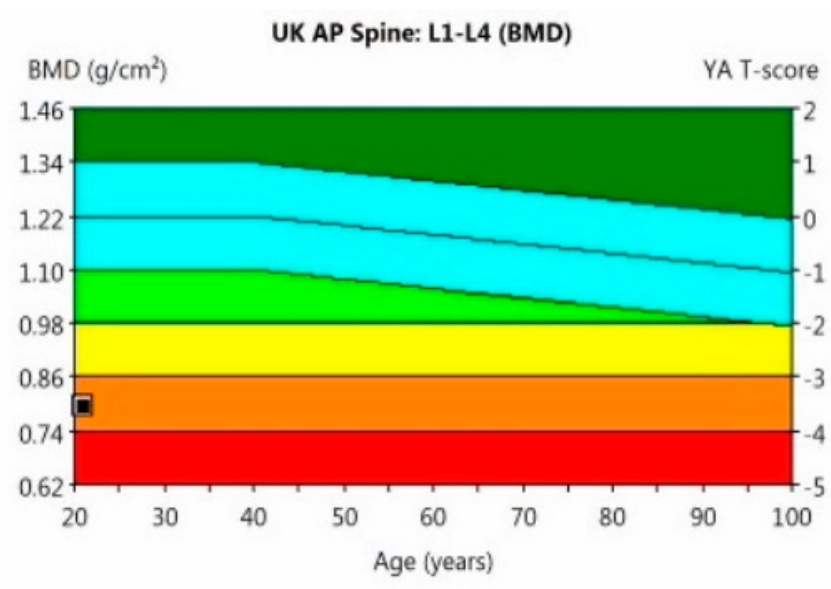

(b)

Figure 3. (a) 23-year-old male with PMM2-CDG (BMI $\left.17 \mathrm{~kg} / \mathrm{m}^{2}\right)$. DEXA scan: Results: bone mineral density below expected range for age. Evidence of moderate compression at T8 and T9 vertebrae. (b) DEXA scan: Lumbar spine (L1-L4): T-score -3.5 , Z-score -3.5 , bone mineral density $0.8 \mathrm{~g} / \mathrm{cm}^{3}$.

Importantly, a multidisciplinary approach with pain specialist, rheumatologist, endocrinologist, metabolic specialist, physiotherapist and dietician is key to successful management of bone health in this group of disorders.

\subsection{Therapies and Bone Health}

Some CDG types including PGM1-CDG and TMEM165-CDG, characterized by an undergalactosylation of the $N$-glycans have shown good responses to galactose supplementation [68,69]. Additionally, deficient import of UDP-Gal into the ER or the Golgi, required by $\beta 1$,4-galactosyltransferase to elongate the growing glycan chain, has been documented in SLC35A2-CDG [70]. Although in this condition, galactose supplementation has improved glycosylation, it has not been clear whether it has had an impact on clinical manifestations of the disease including bones anomalies [70]. Apart from galactose, mannose has been utilized as a therapy in MPI-CDG $[9,10]$ and has been shown to restore endocrine function and coagulation and alleviates enteropathy, but does not always reverse progressive hepatic involvement [71]. The long-term effect of mannose on skeletal outcomes needs careful attention. As a result of the UDP-fucose transporter defect and impaired fucosylation in the Golgi in SLC35C1-CDG, patients affected with this CDG type have been benefited from fucose supplementation [72,73]. A decreased infection rates and 
improved expression of E- and P-selectin ligands and restored neutrophil numbers have been documented [72,73].

Although biochemical and haematological parameters improved with these therapeutic approaches, the impact on bone tissue remains unclear. Long-term prospective observational studies will elucidate whether the bone health in CDGs improves with the nutritional supplementation and/or new therapeutic approaches including pharmacological chaperone, antisense or gene therapies (discussed in detail in $[9,10])$.

\section{Conclusions}

CDGs should be considered as a differential diagnosis of skeletal dysplasia, especially in multiorgan and systemic involvement. It is particularly important for CDGs with prenatal-onset skeletal dysplasia which is associated with severe clinical outcomes. Thus, early diagnosis is key to family genetic counselling.

Skeletal involvement in CDGs is underestimated and thus should be more carefully investigated and managed shortly after a diagnosis is made. In adult CDG patients screening for additional risk factors for osteoporosis should be considered. There is a scope for utilizing bone markers in monitoring of the bone tissue dynamics. The anticipated expansion in the therapeutic strategies is hoped to impact the bone health in CDGs and prevent skeletal complications.

Author Contributions: Project administration: P.L., A.T.-S., A.J.-S.; Investigation: P.L., K.M.S., E.C., A.T.-S., A.J.-S.; Supervision: A.T.-S., A.J.-S.; Writing-original draft: P.L.; Writing-review and editing: P.L., K.M.S., E.C., A.T.-S., A.J.-S. All authors have read and agreed to the published version of the manuscript.

Funding: The study was funded by the Children's Memorial Health Institute intramural grant S190/2020.

Institutional Review Board Statement: The study was conducted according to the guidelines of the Declaration of Helsinki, and approved by the Ethics Committee of the Children's Memorial Health Institute, Number 23/KBE/2020, Warsaw, Poland.

Informed Consent Statement: Informed consent was obtained from all subjects involved in the study.

Data Availability Statement: All data generated or analysed during this study are included in this published article.

Conflicts of Interest: The authors declare no conflict of interest.

\section{Abbreviations}

$\begin{array}{ll}\text { ALG3 } & \text { alpha-1,3-mannosyltransferase; } \\ \text { ALG6 } & \text { alpha-1,3-glucosyltransferase; } \\ \text { ALG9 } & \text { alpha-1,2-mannosyltransferase; } \\ \text { ALG12 } & \text { alpha-1,6-mannosyltransferase; } \\ \text { CDGs } & \text { congenital disorders of glycosylation; } \\ \text { COG } & \text { component of oligomeric Golgi complex; } \\ \text { CSGalNAcT1 } & \text { chondroitin sulphate N-acetylgalactosaminyltransferase-1; } \\ \text { EDS } & \text { Ehlers-Danlos syndrome; } \\ \text { GPI } & \text { glycosylphosphatidylinositol; } \\ \text { GPI-BD } & \text { glycosylphosphatidylinositol biosynthesis defects; } \\ \text { LLO } & \text { lipid-linked oligosaccharide; } \\ \text { PGM3 } & \text { phosphoglucomutase 3; } \\ \text { PMM2 } & \text { phosphomannomutase 2; } \\ \text { SLC35D1 } & \text { UDP-glucuronic acid/UDP-N-acetylgalactosamine transporter; } \\ \text { TMEM165 } & \text { transmembrane protein 165. }\end{array}$




\section{References}

1. Péanne, R.; de Lonlay, P.; Foulquier, F.; Kornak, U.; Lefeber, D.J.; Morava, E.; Pérez, B.; Seta, N.; Thiel, C.; Van Schaftingen, E.; et al. Congenital disorders of glycosylation (CDG): Quo vadis? Eur. J. Med. Genet. 2018, 61, 643-663. [CrossRef] [PubMed]

2. Francisco, R.; Marques-Da-Silva, D.; Brasil, S.A.; Pascoal, C.; Ferreira, V.D.R.; Morava, E.; Jaeken, J. The challenge of CDG diagnosis. Mol. Genet. Metab. 2019, 126, 1-5. [CrossRef]

3. Kinoshita, T. Biosynthesis and biology of mammalian GPI-anchored proteins. Open Biol. 2020, 10, 190290. [CrossRef]

4. Brasil, S.; Pascoal, C.; Francisco, R.; Marques-Da-Silva, D.; Andreotti, G.; Videira, P.A.; Morava, E.; Jaeken, J.; Ferreira, V.D.R. CDG Therapies: From bench to bedside. Int. J. Mol. Sci. 2018, 19, 1304. [CrossRef] [PubMed]

5. Abu Bakar, N.; Lefeber, D.J.; van Scherpenzeel, M. Clinical glycomics for the diagnosis of congenital disorders of glycosylation. J. Inherit. Metab. Dis. 2018, 41, 499-513. [CrossRef] [PubMed]

6. Zeevaert, R.; De Zegher, F.; Sturiale, L.; Garozzo, D.; Smet, M.-H.; Moens, M.; Matthijs, G.; Jaeken, J. Bone dysplasia as a key feature in three patients with a novel congenital disorder of glycosylation (CDG) type ii due to a deep intronic splice mutation in TMEM165. JIMD Rep. Case Res. Rep. 2012, 8, 145-152. [CrossRef]

7. Coman, D.; Bostock, D.; Hunter, M.; Kannu, P.; Irving, M.; Mayne, V.; Fietz, M.; Jaeken, J.; Savarirayan, R. Primary skeletal dysplasia as a major manifesting feature in an infant with congenital disorder of glycosylation type Ia. Am. J. Med. Genet. Part A 2008, 146, 389-392. [CrossRef]

8. Schiff, M.; Roda, C.; Monin, M.L.; Arion, A.; Barth, M.; Bednarek, N.; Bidet, M.; Bloch, C.; Boddaert, N.; Borgel, D.; et al. Clinical, laboratory and molecular findings and long-term follow-up data in 96 French patients with PMM2-CDG (phosphomannomutase 2-congenital disorder of glycosylation) and review of the literature. J. Med. Genet. 2017, 54, 843-851. [CrossRef] [PubMed]

9. Witters, P.; Cassiman, D.; Morava, E. Nutritional therapies in congenital disorders of glycosylation (CDG). Nutrients 2017, 9, 1222. [CrossRef] [PubMed]

10. Verheijen, J.; Tahata, S.; Kozicz, T.; Witters, P.; Morava, E. Therapeutic approaches in congenital disorders of glycosylation (CDG) involving N-linked glycosylation: An update. Genet. Med. 2019, 22, 268-279. [CrossRef]

11. Altassan, R.; Péanne, R.; Jaeken, J.; Barone, R.; Bidet, M.; Borgel, D.; Brasil, S.; Cassiman, D.; Cechova, A.; Coman, D.; et al. International clinical guidelines for the management of phosphomannomutase 2-congenital disorders of glycosylation: Diagnosis, treatment and follow up. J. Inherit. Metab. Dis. 2019, 42, 5-28. [CrossRef] [PubMed]

12. Kjaergaard, S.; Müller, J.; Skovby, F. Prepubertal growth in congenital disorder of glycosylation type Ia (CDG-Ia). Arch. Dis. Child. 2002, 87, 324-327. [CrossRef]

13. Monin, M.-L.; Mignot, C.; De Lonlay, P.; Héron, B.; Masurel, A.; Mathieu-Dramard, M.; Lenaerts, C.; Thauvin, C.; Gérard, M.; Roze, E.; et al. 29 French adult patients with PMM2-congenital disorder of glycosylation: Outcome of the classical pediatric phenotype and depiction of a late-onset phenotype. Orphanet. J. Rare Dis. 2014, 9, 1-9. [CrossRef]

14. Witters, P.; Honzik, T.; Bauchart, E.; Altassan, R.; Pascreau, T.; Bruneel, A.; Vuillaumier, S.; Seta, N.; Borgel, D.; Matthijs, G.; et al. Long-term follow-up in PMM2-CDG: Are we ready to start treatment trials? Genet. Med. 2019, 21, 1181-1188. [CrossRef]

15. Miller, B.; Duffy, M.; Sarafoglou, K. rhIGF-1 therapy for growth failure and IGF-1 deficiency in congenital disorder of glycosylation ia (PMM2 Deficiency). Growth Horm. IGF Res. 2010, 20, 79-80. [CrossRef]

16. Krasnewich, D.; O’Brien, K.; Sparks, S. Clinical features in adults with congenital disorders of glycosylation type Ia (CDG-Ia). Am. J. Med. Genet. Part C Semin. Med. Genet. 2007, 145, 302-306. [CrossRef]

17. Barone, R.; Pavone, V.; Pennisi, P.; Fiumara, A.; Fiore, C.E. Assessment of skeletal status in patients with congenital disorder of glycosylation type IA. Int. J. Tissue React. 2002, 24, 23-28. [PubMed]

18. Garel, C.; Baumann, C.; Besnard, M.; Ogier, H.; Jaeken, J.; Hassan, M. Carbohydrate-deficient glycoprotein syndrome type I: A new cause of dysostosis multiplex. Skelet. Radiol. 1998, 27, 43-45. [CrossRef] [PubMed]

19. Eyskens, F.; Ceuterick, C.; Martin, J.-J.; Janssens, G.; Jaeken, J. Carbohydrate-deficient glycoprotein syndrome with previously unreported features. Acta Paediatr. 1994, 83, 892-896. [CrossRef]

20. Clayton, P.T.; Winchester, B.G.; Keir, G. Hypertrophic obstructive cardiomyopathy in a neonate with the carbohydrate-defi-cient glycoprotein syndrome. J. Inherit. Metab. Dis. 1992, 15, 857-861. [CrossRef]

21. Kranz, C.; Basinger, A.A.; Güçsavaş-Çalıkoğlu, M.; Sun, L.; Powell, C.M.; Henderson, F.W.; Aylsworth, A.S.; Freeze, H. Expanding spectrum of congenital disorder of glycosylation Ig (CDG-Ig): Sibs with a unique skeletal dysplasia, hypogammaglobulinemia, cardiomyopathy, genital malformations, and early lethality. Am. J. Med. Genet. Part A 2007, 143, 1371-1378. [CrossRef] [PubMed]

22. Murali, C.; Lu, J.T.; Jain, M.; Liu, D.S.; Lachman, R.; Gibbs, R.A.; Lee, B.H.; Cohn, D.; Campeau, P.M. Diagnosis of ALG12-CDG by exome sequencing in a case of severe skeletal dysplasia. Mol. Genet. Metab. Rep. 2014, 1, 213-219. [CrossRef]

23. Eteson, D.J.; Beluffi, G.; Burgio, G.; Belloni, C.; Lachman, R.S.; Rimoin, D.L. Pseudodiastrophic dysplasia: A distinct newborn skeletal dysplasia. J. Pediatr. 1986, 109, 635-641. [CrossRef]

24. Byrne, A.B.; Mizumoto, S.; Arts, P.; Yap, P.; Feng, J.; Schreiber, A.; Babic, M.; King-Smith, S.L.; Barnett, C.P.; Moore, L.; et al. Pseudodiastrophic dysplasia expands the known phenotypic spectrum of defects in proteoglycan biosynthesis. J. Med. Genet. 2020, 57, 454-460. [CrossRef] [PubMed]

25. Yap, P.; Liebelt, J.E.; Amor, D.J.; Moore, L.; Savarirayan, R. Pseudodiastrophic dysplasia: Two cases delineating and expanding the pre and postnatal phenotype. Am. J. Med. Genet. Part A 2016, 170, 1363-1366. [CrossRef] [PubMed] 
26. Lepais, L.; Cheillan, D.; Frachon, S.C.; Hays, S.; Matthijs, G.; Panagiotakaki, E.; Abel, C.; Edery, P.; Rossi, M. ALG3-CDG: Report of two siblings with antenatal features carrying homozygous p.Gly96Arg mutation. Am. J. Med. Genet. Part A 2015, 167, 2748-2754. [CrossRef]

27. Gillessen-Kaesbach, G.; Meinecke, P.; Garrett, C.; Padberg, B.C.; Rehder, H.; Passarge, E. New autosomal recessive lethal disorder with polycystic kidneys type Potter I, characteristic face, microcephaly, brachymelia, and congenital heart defects. Am. J. Med. Genet. 1993, 45, 511-518. [CrossRef] [PubMed]

28. Nishimura, G.; Nakayama, M.; Fuke, Y.; Suehara, N. A lethal osteochondrodysplasia with mesomelic brachymelia, round pelvis, and congenital hepatic fibrosis: Two siblings born to consanguineous parents. Pediatr. Radiol. 1998, 28, 43-47. [CrossRef]

29. Tham, E.; Eklund, E.A.; Hammarsjö, A.; Bengtson, P.; Geiberger, S.; Lagerstedt-Robinson, K.; Malmgren, H.; Nilsson, D.; Grigelionis, G.; Conner, P.; et al. A novel phenotype in N-glycosylation disorders: Gillessen-Kaesbach-Nishimura skeletal dysplasia due to path-ogenic variants in ALG9. Eur. J. Hum. Genet. 2016, 24, 198-207. [CrossRef]

30. AlSubhi, S.; Alhashem, A.; Alazami, A.; Tlili, K.; Alshahwan, S.; Lefeber, D.; Alkuraya, F.S.; Tabarki, B.; Baumgartner, M.; Patterson, M.; et al. Further delineation of the ALG9-CDG phenotype. JIMD Rep. 2015, 27, 107-112. [CrossRef]

31. Drijvers, J.M.; Lefeber, D.J.; de Munnik, S.A.; Pfundt, R.; van de Leeuw, N.; Marcelis, C.; Thiel, C.; Koerner, C.; Wevers, R.A.; Morava, E. Skeletal dysplasia with brachytelephalangy in a patient with a congenital disorder of glycosylation due to ALG6 gene mutations. Clin. Genet. 2010, 77, 507-509. [CrossRef] [PubMed]

32. Sun, L.; Eklund, E.A.; Van Hove, J.L.; Freeze, H.H.; Thomas, J.A. Clinical and molecular characterization of the first adult con-genital disorder of glycosylation (CDG) type Ic patient. Am. J. Med. Genet. A 2005, 137, 22-26. [CrossRef]

33. Sassi, A.; Lazaroski, S.; Wu, G.; Haslam, S.M.; Fliegauf, M.; Mellouli, F.; Patiroglu, T.; Unal, E.; Ozdemir, M.A.; Jouhadi, Z.; et al. Hypomorphic homozygous mutations in phosphoglucomutase 3 (PGM3) impair immunity and increase serum IgE levels. J. Allergy Clin. Immunol. 2014, 133, 1410-1419. [CrossRef] [PubMed]

34. Stray-Pedersen, A.; Backe, P.H.; Sorte, H.S.; Mørkrid, L.; Chokshi, N.Y.; Erichsen, H.C.; Gambin, T.; Elgstøen, K.B.; Bjørås, M.; Wlodarski, M.W. PGM3 mutations cause a congenital disorder of glycosylation with severe im-munodeficiency and skeletal dysplasia. Am. J. Hum. Genet. 2014, 95, 96-107. [CrossRef]

35. Inoue, S.; Ishii, A.; Shirotani, G.; Tsutsumi, M.; Ohta, E.; Nakamura, M.; Mori, T.; Inoue, T.; Nishimura, G.; Ogawa, A.; et al. Case of desbuquois dysplasia type 1: Potentially lethal skeletal dysplasia. Pediatr. Int. 2014, 56, e26-e29. [CrossRef] [PubMed]

36. Pacheco-Cuéllar, G.; Gauthier, J.; Désilets, V.; Lachance, C.; Lemire-Girard, M.; Rypens, F.; Le Deist, F.; Decaluwe, H.; Duval, M.; Soglio, D.B.-D.; et al. A novel PGM3 mutation is associated with a severe phenotype of bone marrow failure, severe combined immunodeficiency, skeletal dysplasia, and congenital malformations. J. Bone Miner. Res. 2017, 32, 1853-1859. [CrossRef]

37. Morava, E.; Zeevaert, R.; Korsch, E.; Huijben, K.; Wopereis, S.; Matthijs, G.; Keymolen, K.; Lefeber, D.J.; De Meirleir, L.; Wevers, R.A. A common mutation in the COG7 gene with a consistent phenotype including microcephaly, adducted thumbs, growth retar-dation, VSD and episodes of hyperthermia. Eur. J. Hum. Genet. 2007, 15, 638-645. [CrossRef]

38. Wu, X.; Steet, R.A.; Bohorov, O.; Bakker, J.A.; Newell, J.; Krieger, M.; Spaapen, L.; Kornfeld, S.; Freeze, H.H. Mutation of the COG complex subunit gene COG7 causes a lethal congenital disorder. Nat. Med. 2004, 10, 518-523. [CrossRef]

39. Foulquier, F.; Vasile, E.; Schollen, E.; Callewaert, N.; Raemaekers, T.; Quelhas, D.; Jaeken, J.; Mills, P.; Winchester, B.; Krieger, M.; et al. Conserved oligomeric golgi complex subunit 1 deficiency reveals a previously uncharacterized con-genital disorder of glycosylation type II. Proc. Natl. Acad. Sci. USA 2006, 103, 3764-3769. [CrossRef]

40. Foulquier, F.; Ungar, D.; Reynders, E.; Zeevaert, R.; Mills, P.; García-Silva, M.T.; Briones, P.; Winchester, B.; Morelle, W.; Krieger, M.; et al. A new inborn error of glycosylation due to a Cog8 deficiency reveals a critical role for the Cog1-Cog8 interaction in COG complex formation. Hum. Mol. Genet. 2007, 16, 717-730. [CrossRef]

41. Vodopiutz, J.; Mizumoto, S.; Lausch, E.; Rossi, A.; Unger, S.; Janocha, N.; Costantini, R.; Seidl, R.; Greber-Platzer, S.; Yamada, S.; et al. Chondroitin sulfateN-acetylgalactosaminyltransferase-1 (CSGalNAcT-1) deficiency results in a mild skeletal dysplasia and joint laxity. Hum. Mutat. 2016, 38, 34-38. [CrossRef] [PubMed]

42. Mizumoto, S.; Janecke, A.R.; Sadeghpour, A.; Povysil, G.; McDonald, M.T.; Unger, S.; Greber-Platzer, S.; Deak, K.L.; Katsanis, N.; Superti-Furga, A.; et al. CSGALNACT1-congenital disorder of glycosylation: A mild skeletal dysplasia with advanced bone age. Hum. Mutat. 2019, 41, 655-667. [CrossRef] [PubMed]

43. Rautengarten, C.; Quarrell, O.W.; Stals, K.; Caswell, R.C.; De Franco, E.; Baple, E.; Burgess, N.; Jokhi, R.; Heazlewood, J.L.; Offiah, A.C.; et al. A hypomorphic allele of SLC35D1 results in Schneckenbecken-like dysplasia. Hum. Mol. Genet. 2019, 28, 3543-3551. [CrossRef] [PubMed]

44. Nikkels, P.G.; Stigter, R.H.; Knol, I.E.; van der Harten, H.J. Schneckenbecken dysplasia, radiology, and histology. Pediatr. Radiol. 2001, 31, 27-30. [CrossRef] [PubMed]

45. Faiyaz-Ul-Haque, M.; Zaidi, S.H.; Al-Ali, M.; Al-Mureikhi, M.S.; Kennedy, S.; Al-Thani, G.; Tsui, L.C.; Teebi, A.S. A novel missense mutation in the galactosyltransferase-I (B4GALT7) gene in a family exhibiting facioskeletal anomalies and Ehlers-Danlos syn-drome resembling the progeroid type. Am. J. Med. Genet. A. 2004, 128, 39-45. [CrossRef]

46. Kresse, H.; Rosthøj, S.; Quentin, E.; Hollmann, J.; Glössl, J.; Okada, S.; Tønnesen, T. Glycosaminoglycan-free small proteoglycan core protein is secreted by fibroblasts from a patient with a syndrome resembling progeroid. Am. J. Hum. Genet. 1987, 41, 436-453. [PubMed]

47. Baasanjav, S.; Al-Gazali, L.; Hashiguchi, T.; Mizumoto, S.; Fischer-Zirnsak, B.; Horn, D.; Seelow, D.; Ali, B.R.; Aziz, S.A.; Langer, R.; et al. Faulty initiation of proteoglycan synthesis causes cardiac and joint defects. Am. J. Hum. Genet. 2011, 89, 15-27. [CrossRef] 
48. Seidler, D.G.; Faiyaz-Ul-Haque, M.; Hansen, U.; Yip, G.W.; Zaidi, S.H.; Teebi, A.S.; Kiesel, L.; Götte, M. Defective glycosylation of decorin and biglycan, altered collagen structure, and abnormal phenotype of the skin fibroblasts of an Ehlers-Danlos syndrome patient carrying the novel Arg270Cys substitution in galactosyltransferase I (beta4GalT-7). J. Mol. Med. 2006, 84, 583-594. [CrossRef]

49. Ritelli, M.; Cinquina, V.; Giacopuzzi, E.; Venturini, M.; Chiarelli, N.; Colombi, M. Further defining the phenotypic spectrum of B3GAT3 mutations and literature review on linkeropathy syndromes. Genes 2019, 10, 631. [CrossRef]

50. Foulquier, F.; Amyere, M.; Jaeken, J.; Zeevaert, R.; Schollen, E.; Race, V.; Bammens, R.; Morelle, W.; Rosnoblet, C.; Legrand, D.; et al. TMEM165 deficiency causes a congenital disorder of glycosylation. Am. J. Hum. Genet. 2012, 91, 15-26. [CrossRef] [PubMed]

51. Carmody, L.C.; Blau, H.; Danis, D.; Zhang, X.A.; Gourdine, J.P.; Vasilevsky, N.; Krawitz, P.; Thompson, M.D.; Robinson, P.N. Significantly different clinical phenotypes associated with mutations in synthesis and transamidase+remodeling glycosylphosphatidylinositol (GPI)-anchor biosynthesis genes. Orphanet. J. Rare Dis. 2020, 15, 40. [CrossRef]

52. Horn, D.; Krawitz, P.; Mannhardt, A.; Korenke, G.C.; Meinecke, P. Hyperphosphatasia-mental retardation syndrome due to PIGV mutations: Expanded clinical spectrum. Am. J. Med. Genet. Part A 2011, 155, 1917-1922. [CrossRef] [PubMed]

53. Altassan, R.; Fox, S.; Poulin, C.; Buhas, D. Hyperphosphatasia with mental retardation syndrome, expanded phenotype of PIGL related disorders. Mol. Genet. Metab. Rep. 2018, 15, 46-49. [CrossRef] [PubMed]

54. Rabe, P.; Haverkamp, F.; Emons, D.; Rosskamp, R.; Zerres, K.; Passarge, E. Syndrome of developmental retardation, facial and skeletal anomalies, and hyperphosphatasia in two sisters: Nosology and genetics of the coffin-siris syndrome. Am. J. Med. Genet. 1991, 41, 350-354. [CrossRef]

55. Marcelis, C.L.; Rieu, P.; Beemer, F.; Brunner, H.G. Severe mental retardation, epilepsy, anal anomalies, and distal phalangeal hypoplasia in siblings. Clin. Dysmorphol. 2007, 16, 73-76. [CrossRef] [PubMed]

56. Horn, D.; Schottmann, G.; Meinecke, P. Hyperphosphatasia with mental retardation, brachytelephalangy, and a distinct facial gestalt: Delineation of a recognizable syndrome. Eur. J. Med. Genet. 2010, 53, 85-88. [CrossRef]

57. Thompson, M.D.; Nezarati, M.M.; Gillessen-Kaesbach, G.; Meinecke, P.; Mendoza, R.; Mornet, E.; Brun-Heath, I.; Squarcioni, C.P.; Legeai-Mallet, L.; Munnich, A.; et al. Hyperphosphatasia with seizures, neurologic deficit, and characteristic facial features: Five new patients with Mabry syndrome. Am. J. Med. Genet. A 2010, 52, 1661-1669. [CrossRef]

58. Krawitz, P.; Murakami, Y.; Hecht, J.; Krüger, U.; Holder, S.E.; Mortier, G.; Chiaie, B.D.; De Baere, E.; Thompson, M.D.; Roscioli, T.; et al. Mutations in PIGO, a member of the GPI-anchor-synthesis pathway, cause hyperphosphatasia with mental retardation. Am. J. Hum. Genet. 2012, 91, 146-151. [CrossRef]

59. Morren, M.-A.; Jaeken, J.; Visser, G.; Salles, I.; Van Geet, C.; BioResource, N.; Simeoni, I.; Turro, E.; Freson, K. PIGO deficiency: Palmoplantar keratoderma and novel mutations. Orphanet. J. Rare Dis. 2017, 12, 101. [CrossRef]

60. Schrier Vergano, S.; Santen, G.; Wieczorek, D.; Wollnik, B.; Matsumoto, N.; Deardorff, M.A. Coffin-Siris Syndrome; Adam, M.P., Ardinger, H.H., Pagon, R.A., Wallace, S.E., Bean, L.J.H., Stephens, K., Amemiya, A., Eds.; GeneReviews: Seattle, WA, USA, 1993.

61. Gulberti, S.; Jacquinet, J.-C.; Chabel, M.; Ramalanjaona, N.; Magdalou, J.; Netter, P.; Coughtrie, M.W.H.; Ouzzine, M.; FournelGigleux, S. Chondroitin sulfate N-acetylgalactosaminyltransferase-1 (CSGalNAcT-1) involved in chondroitin sulfate initiation: Impact of sulfation on activity and specificity. Glycobiology 2011, 22, 561-571. [CrossRef]

62. Hiraoka, S.; Furuichi, T.; Nishimura, G.; Shibata, S.; Yanagishita, M.; Rimoin, D.L.; Superti-Furga, A.; Nikkels, P.G.; Ogawa, M.; Katsuyama, K.; et al. Nucleotide-sugar transporter SLC35D1 is critical to chondroitin sulfate synthesis in cartilage and skeletal development in mouse and human. Nat. Med. 2007, 13, 1363-1367. [CrossRef] [PubMed]

63. Bammens, R.; Mehta, N.; Race, V.; Foulquier, F.; Jaeken, J.; Tiemeyer, M.; Steet, R.; Matthijs, G.; Flanagan-Steet, H. Abnormal cartilage development and altered N-glycosylation in Tmem165-deficient zebrafish mirrors the phenotypes associated with TMEM165-CDG. Glycobiology 2015, 25, 669-682. [CrossRef] [PubMed]

64. Stepien, K.M. Hormonal dysfunction in adult patients affected with inherited metabolic disorders. J. Mother Child 2020, $24,21-31$.

65. Noman, K.; Hendriksz, C.; Radcliffe, G.; Roncaroli, F.; Moreea, S.; Hussain, A.; Stepien, K.M. Clinical outcomes in an adult patient with mannose phosphate isomerase-congenital disorder of glycosylation who discontinued mannose therapy. Mol. Genet. Metab. Rep. 2020, 25, 100646. [CrossRef] [PubMed]

66. Colhoun, H.O.; Treacy, E.P.; MacMahon, M.; Rudd, P.M.; FitzGibbon, M.; O'Flaherty, R.; Stepien, K.M. Validation of an automated ultraperformance liquid chromatography IgG N-glycan analytical method applicable to classical galactosaemia. Ann. Clin. Biochem. Int. J. Lab. Med. 2018, 55, 593-603. [CrossRef] [PubMed]

67. Stepien, K.M.; Colhoun, H.O.; Gautsch, M.; Rubio-Gozalbo, M.E.; Dawson, C.; Lambert, D.; O’Flaherty, R.; Doran, P.; Treacy, E. Reduced bone density in classical galactosaemia, is abnormal glycosylation a factor? Mol. Genet. Metab. 2018, 123, 267-268.

68. Morelle, W.; Potelle, S.; Witters, P.; Wong, S.; Climer, L.; Lupashin, V.; Matthijs, G.; Gadomski, T.; Jaeken, J.; Cassiman, D.; et al. Galactose supplementation in patients with TMEM165-CDG rescues the glycosylation defects. J. Clin. Endocrinol. Metab. 2017, 102, 1375-1386. [CrossRef] [PubMed]

69. Radenkovic, S.; Bird, M.J.; Emmerzaal, T.L.; Wong, S.Y.; Felgueira, C.; Stiers, K.M.; Sabbagh, L.; Himmelreich, N.; Poschet, G.; Wind-molders, P.; et al. The metabolic map into the pathomechanism and treatment of PGM1-CDG. Am. J. Hum. Genet. 2019, 104, 835-846. [CrossRef] 
70. Dörre, K.; Olczak, M.; Wada, Y.; Sosicka, P.; Grüneberg, M.; Reunert, J.; Kurlemann, G.; Fiedler, B.; Biskup, S.; Hörtnagel, K.; et al. A new case of UDP-galactose transporter deficiency (SLC35A2-CDG): Molecular basis, clinical phenotype, and therapeutic approach. J. Inherit. Metab. Dis. 2015, 38, 931-940. [CrossRef]

71. Mention, K.; Lacaille, F.; Valayannopoulos, V.; Romano, S.; Kuster, A.; Cretz, M.; Zaidan, H.; Galmiche, L.; Jaubert, F.; De Keyzer, Y.; et al. Development of liver disease despite mannose treatment in two patients with CDG-Ib. Mol. Genet. Metab. 2008, 93, 40-43. [CrossRef]

72. Marquardt, T.; Lühn, K.; Srikrishna, G.; Freeze, H.H.; Harms, E.; Vestweber, D. Correction of leukocyte adhesion deficiency type II with oral fucose. Blood 1999, 94, 3976-3985. [CrossRef] [PubMed]

73. Cagdas, D.; Yılmaz, M.; Kandemir, N.; Tezcan, I.; Etzioni, A.; Sanal, Ö. A novel mutation in leukocyte adhesion deficiency type II/CDGIIc. J. Clin. Immunol. 2014, 34, 1009-1014. [CrossRef] [PubMed] 